\title{
A comparative assessment of the morphology of Profilicollis altmani (Acanthocephala, Polymorphidae) from crustaceans and shore birds in Peru, with special notes on hook elemental analysis (EDXA), SEM imaging, histopathology, and molecular profile
}

Omar M. Amin ${ }^{1, *}$, Sara M. Rodríguez ${ }^{2}$, Nataliya Rubtsova ${ }^{1}$, Richard A. Heckmann ${ }^{3, a}$, César Peña ${ }^{4}$, Teresa Castro ${ }^{5}$, Felipe Rivera ${ }^{6}$, and Guillermo D’Elía ${ }^{7}$

${ }^{1}$ Institute of Parasitic Diseases, 11445 E. Via Linda 2-419, Scottsdale, AZ 85259, USA

2 Instituto de Ciencias Marinas y Limnológicas, Facultad de Ciencias, Universidad Austral de Chile, Isla Teja s/n, Valdivia 509000, Chile

${ }^{3}$ Department of Biology, Brigham Young University, Provo, UT 84602, USA

${ }^{4}$ Departamento de Acuicultura, Facultad de Oceanografía y Pesquería, Universidad Nacional Federico Villarreal, Francia 726, Miraflores, Lima 15007, Perú

${ }^{5}$ Laboratorio de Patobiología Acuática, Dirección General de Investigaciones en Acuicultura, Instituto del Mar del Perú (IMARPE), Esquina Gamarra y General Valle s/n. Casilla Postal 22, Callao, Perú

${ }^{6}$ Electron Microscopy Facility, Brigham Young University, Provo, UT 84602, USA

${ }^{7}$ Instituto de Ciencias Ambientales y Evolutivas, Facultad de Ciencias, Universidad Austral de Chile, Valdivia, Isla Teja s/n, Valdivia 509000, Chile

Received 24 August 2021, Accepted 17 January 2022, Published online 22 February 2022

\begin{abstract}
The morphology of cystacanths and adults of Profilicollis altmani (Perry, 1942) Van Cleave, 1947 (Polymorphidae) were studied from the Pacific mole crab Emerita analoga (Stimpson) (Crustacea, Hippidae) and Belcher's gull Larus belcheri (Vigors) (Aves, Laridae), respectively, in Peru. Comparative morphometrics with accounts of other populations of $P$. altmani from elsewhere off the Pacific and Atlantic coasts of North and South America revealed marked intraspecific population variations. We report scanning electron micrographs (SEM) of new features, not before noted or captured in line drawings by earlier observers. We further present microscope images that reveal internal details not previously reported or possible to see with SEM. Energy dispersive X-ray analysis (EDXA) revealed unusual patterns in the chemistry of proboscis hooks especially the high sulfur and diminished phosphorous and calcium in hook tips and low sulfur and high levels of phosphorous and calcium at mid hooks. The size and shape of all hooks of the cystacanths are reported for the first time. Histopathological studies in L. belcheri from Peru are also included. Cystacanths of $P$. altmani from California were also analyzed for molecular patterns and compared with other sequences reported from other locations. The molecular data and the analysis of our new sequences of cytochrome oxidase I (COI) showed that haplotypes of $P$. altmani had low genetic variation; the species is not geographically structured, and within its clade no monophyletic group is formed.
\end{abstract}

Key words: Acanthocephala, Profilicollis altmani cystacanths, Emerita analoga, Adults, Larus belcheri, Peru, Descriptions, EDXA, Molecular profile, Histopathology.

Résumé - Évaluation comparative de la morphologie de Profilicollis altmani (Acanthocephala, Polymorphidae)
de crustacés et d'oiseaux de rivage au Pérou, en particulier l'analyse élémentaire des crochet (EDXA),
l'imagerie SEM, l'histopathologie et le profil moléculaire. La morphologie des cystacanthes et des adultes de
Profilicollis altmani (Perry, 1942) Van Cleave, 1947 (Polymorphidae) a été étudiée, respectivement, à partir du
crustacé Emerita analoga (Stimpson) (Crustacea, Hippidae) et du Goéland Siméon Larus belcheri (Vigors) (Aves,
Laridae), au Pérou. La morphométrie comparative avec des données d'autres populations de P. altmani d'autres
localités au large des côtes du Pacifique et de l'Atlantique de l'Amérique du Nord et du Sud a révélé des variations
intraspécifiques marquées des populations. Nous rapportons des nouvelles observations de microscopie électronique
à balayage, non notées auparavant ou non capturées dans des dessins au trait par des observateurs antérieurs. Nous

*Corresponding author: omaramin@aol.com

${ }^{\mathrm{a}}$ Deceased.

This is an Open Access article distributed under the terms of the Creative Commons Attribution License (https://creativecommons.org/licenses/by/4.0), which permits unrestricted use, distribution, and reproduction in any medium, provided the original work is properly cited. 
présentons en outre des images au microscope qui révèlent des détails internes qui n'ont pas été signalés auparavant ni possibles à voir avec MET. L'analyse aux rayons X à dispersion d'énergie (EDXA) a révélé des modèles inhabituels dans la chimie des crochets de la trompe, en particulier la teneur élevée en soufre et une diminution du phosphore et du calcium dans les pointes des crochets et des niveaux faibles en soufre et en phosphore et en calcium au milieu des crochets. La taille et la forme de tous les crochets des cystacanthes sont décrites pour la première fois. Des études histopathologiques sur L. belcheri du Pérou sont également incluses. Les cystacanthes de P. altmani de Californie ont également été analysés pour les modèles moléculaires et comparés à d'autres séquences rapportées d'autres endroits. Les données moléculaires et l'analyse de nos nouvelles séquences de cytochrome oxydase I (COI) ont montré que les haplotypes de $P$. altmani avaient une faible variation génétique. L'espèce n'est pas structurée géographiquement, et au sein de son clade aucun groupe monophylétique n'est formé.

\section{Introduction}

Cystacanths and adults of Profilicollis altmani (Perry, 1942) Van Cleave, 1947 (Polymorphidae) are common parasites of mole crabs and shore birds, respectively, along the Pacific and Atlantic coasts of North and South America [33, 53, 57, 59]. The acanthocephalan was first described as Filicollis altmani Perry, 1942 from specimens obtained from surf scoters (Melanitta perspicillata Linn. and M. deglandi Bonaparte) at Carmel Bay, California, USA by Perry [54]. It was later described as Polymorphus kenti Van Cleave, 1947 from a herring gull (Larus argentatus Pontoppidan) at New Brunswick, Canada by Van Cleave [75]. Shortly thereafter, it was described as Polymorphus texensis from the sanderling (Crocethia alba Pallas) at Galveston Island, Texas, USA by Webster [77]. In Peru, the same species was described as Polymorphus (Profilicollis) bullocki Mateo, Córdova, Guzmán, 1982 from Larus belcheri Vigors off the Lima coast by Mateo et al. [47]. Gomez-Puerta and Naupay [31] later reported 1 male specimen of $P$. altmani from the same host species and same location. Our Peruvian adult specimens and cystacanths were made available to Omar Amin by César Peña while on a conference tour in Peru in 2009 as whole mounts, and some cystacanths that were in ethanol were used to generate SEM images in 2015. Karl [42] gave an emended description of adults, as Polymorphus altmani, from 8 species of shorebirds and described the cystacanths from the mole crab Emerita analoga (Stimpson) (Hippidae) along the coast of California. Many authors treated these synonyms as independent species and some like Petrochenko [55], as Parafilicollis Petrochenko, 1956), Hoklova [40], and Amin [3] have included them in dichotomous keys based on intraspecific variations in proboscis armature and length of proboscis. We found that Karl's [42] data from about 2000 specimens of $P$. altmani that he studied covered the full range of proboscis measurements and armature known for all 4 synonyms. Two or more species have been recognized as synonyms by Karl [42], Tantaleán and Cárdenas [69], Tantaleán et al. [70], and Nickol et al. [53], among more recent observers. Nickol et al. [52] reintroduced Profilicollis as a genus in the Acanthocephala. Amin [5] provided the definitive list of synonymies as follows: "P. altmani (Perry, 1942) Van Cleave, 1947 [syns. Filicollis altmani Perry, 1942; Parafilicollis altmani (Perry, 1942) Petrochenko, 1956; Polymorphus bullocki Mateo, Cordova et Guzman, 1982; Profilicollis kenti (Van Cleave, 1947) Khokhlova, 1974; Polymorphus kenti Van Cleave, 1947; Parafilicollis kenti (Van Cleave, 1947) Petrochenko, 1956; Falsificollis kenti (Van Cleave, 1947) Yamaguti, 1963 fide
Nickol et al. [53]; Filicollis sphaerocephalus sensu Harrington et Pillbury, 1938 fide Tantaleán et al. [71]; Profilicollis texensis (Webster, 1948) Khokhlova, 1974; Polymorphus (Falsificollis) texensis (Webster, 1948) Yamaguti, 1963 fide Nickol et al. [53]."

Most reports of $P$. altmani are known from the Pacific coast of North and South America (Tables 1, 3). A few reports are also known off the Atlantic coast of North America and South America. For instance, Nickol et al. [53] described cystacanths of $P$. altmani from the mole crab, Emerita talpoida Say from Atlantic Beach, North Carolina, USA. Bullock in Amin [4] identified Polymorphus (Profilicollis) kenti (= P. altmani) cystacanths from an unidentified species of Emerita in Florida, USA and he (Bullock in a pers. Communication to Karl [42]) found cystacanths identified by Karl as $P$. altmani in a species of Emeritus from Florida. Adults were also identified off the Atlantic from "willets and sanderlings in Louisiana and Mississippi" [53]. In South America, cystacanths of P. altmani were also reported from Emerita brasiliensis off Atlantic Uruguay [57]. Constancio [25] examined the prevalence and intensity of $P$. altmani infecting E. analoga from Pismo Beach, California and studied the effects of season and infections on the carotenoid concentration and composition on the mole crab. Most of the host related environmental work pertaining to this species, was, however, reported from Pacific South America. In Chile, sea birds arriving in mass numbers during the summer enhance the spread of acanthocephalan eggs to the environment, producing higher values of infection in E. analoga [58, 80]. The identity of definitive host species was found to be relevant to morphometric and reproductive variations (fecundity) of P. altmani with acanthocephalans of 2 species of Larus attaining larger body size than those in 2 other genera of gulls from the Chilean coast [56]. Iannacone et al. [41] reported a prevalence of $55.3 \%$ and a mean intensity of 2.21 of $P$. altmani cystacanths in a sample of 860 specimens of $E$. analoga from Chorrillos fish market, Lima, Peru; host sex and size were unrelated.

Profilicollis altmani can also successfully infect mammals with ensuing potentially serious outcomes, which may occasionally represent a public health hazard. Worms introduced to rats, mice, hamsters, and pups have produced viable infections detectable in the body cavity and the walls of the small and large intestines. There is potential for risk for humans who eat infected sand crabs [70]. "Muy muy" (E. analoga) heavily infected with cystacanths consumed by humans in various forms on the southern beaches of Lima have been evaluated as a cause of a potential public health problem among 
Table 1. Morphometrics of cystacanths of Profilicollis altmani from the USA, Peru, Chile, and Uruguay.

\begin{tabular}{|c|c|c|c|c|c|c|}
\hline \multirow[t]{2}{*}{ Study site } & \multicolumn{2}{|c|}{ USA } & \multicolumn{2}{|r|}{ Peru } & \multirow{2}{*}{$\begin{array}{c}\text { Chile } \\
\text { Lenga Pacific }\end{array}$} & \multirow{2}{*}{$\begin{array}{c}\text { Uruguay } \\
\text { Arachapa beach Atlantic }\end{array}$} \\
\hline & California Pacific & North Carolina Atlantic & Chorrillos, Lima Pacific & Playa de Pasamayo, Lima Pacific & & \\
\hline Host & Emerita analoga & Emerita. talpoida & Emerita analoga & Emerita analoga & Emerita analoga & Emerita brasilensis \\
\hline Source & Karl (1967) & Nickol et al. (2002) & This study & Mateo et al. (1983) & $\overline{\text { Balboa et al. (2009) }}$ & $\overline{\text { RodrÚguez \& DElÚa (2016) }}$ \\
\hline Total body length* & $5300-7810(750)^{* *}$ & 3986-6017 (4949) & $4525-6675(5555)$ & $5500-7500 * * *$ & $5000-6500(5700)$ & $4500-6200(5533)$ \\
\hline Maximum body width & $260-400(360)$ & $624-845$ (663) & $750-975(884)$ & 890-1130 & $470-1490(1143)$ & 660-915 (755) \\
\hline \multicolumn{7}{|l|}{ Proboscis } \\
\hline Shape & Ovoid & Ovoid & Ovoid & Ovoid & Ovoid & Ovoid \\
\hline Length & 750-800 (Figs. 18, 20) & $518-648(571)$ & $416-728(632)$ & $450-600(550)$ & 500-900 (696) & $505-730(608)$ \\
\hline Width & 400-500 (Figs. 18, 20) & 230-364 (269) & $250-458(352)$ & $260-390(330)$ & $329-600(456)$ & $383-610(485)$ \\
\hline Rows of hooks & $21-35(7)$ & 28 & 26-34 (29) & $27-33$ & $26-30$ & 26-29 \\
\hline Hook/row & $10-15(13)$ & 12 & $13-16(14.5)$ & $13-15$ & $14-16$ & $14-15$ \\
\hline \multicolumn{7}{|l|}{ Length of hooks } \\
\hline Apical & $30-50$ & $34-43(37)$ & $35-45(38)$ & 42 & 56 & $41-48(44)$ \\
\hline Medial & $30-60$ & $41-53(45)$ & $35-43(39)$ & 35 & 73 & $48-61(54)$ \\
\hline Basal & $50-70$ & $43-57(52)$ & $50-60(55)$ & 53 & 90 & $52-79(64)$ \\
\hline \multicolumn{7}{|l|}{ Proboscis receptacle } \\
\hline Length & $1720-2860(2380)$ & 1718-2026 (1868) & 1775-2900 (2309) & $1870-3000(2380)$ & $1400-2970(2562)$ & 1600-2010 (1783) \\
\hline Width & $220-410(230)$ & - & $200-400$ (294) & - & $240-470(338)$ & $318-450(369)$ \\
\hline \multicolumn{7}{|l|}{ Neck } \\
\hline Length & $1140-1830(1700)$ & $1000-1740(1512)$ & $950-1600(1180)$ & $1000-1600(1210)$ & $850-1690$ (1232) & 805-1100 (939) \\
\hline Width & $290-470$ & $336-470(406)$ & $250-425(361)$ & - & $350-580(473)$ & $379-595(461)$ \\
\hline \multicolumn{7}{|l|}{ Lemnisci } \\
\hline Length & Variable unequal & $1037-1440(1250)$ & $925-2400(1580)$ & $1300-1900(1550)$ & $1290-2000(1642)$ & - \\
\hline Width & - & - & $62-250(155)$ & - & 100-340 (181) & - \\
\hline
\end{tabular}

* Total body length includes the proboscis, neck, and the 3 trunk regions. Specimens with retracted tail are not used. Measurements of each developing trunk region and incipient testes are not included separately because of their extreme variability in the growing cystacanths.

** Range (mean) in micrometers in all measurements.

Described as Polymorphus (Profilicollis) bulloki. 
Table 2. The size of 15 hooks in one longitudinal row on the proboscides of 10 cystacanths of Profilicollis altmani from Emerita analoga in Peru.

\begin{tabular}{lcc}
\hline Hook no. & Hook length & Hook width at base \\
\hline 1 & $35-45(38)^{*}$ & $9-14(11)$ \\
2 & $37-45(40)$ & $11-16(12)$ \\
3 & $39-45(42)$ & $12-17(15)$ \\
4 & $38-45(41)$ & $14-17(16)$ \\
5 & $30-45(38)$ & $15-20(19)$ \\
6 & $21-40(31)$ & $10-18(13)$ \\
7 & $30-40(35)$ & $10-16(13)$ \\
8 & $35-45(37)$ & $10-19(14)$ \\
9 & $35-50(40)$ & $10-20(14)$ \\
10 & $37-50(43)$ & $12-20(15)$ \\
11 & $40-57(47)$ & $11-20(15)$ \\
12 & $42-57(49)$ & $12-19(15)$ \\
13 & $42-58(51)$ & $12-19(14)$ \\
14 & $45-57(52)$ & $11-19(13)$ \\
15 & $50-60(55)$ & $10-19(12)$ \\
\hline
\end{tabular}

* Range (mean) in micrometers.

500 people surveyed [50]. Likewise, domestic dogs were reported foraging on mole crabs at Curiñanco beach, southern Chile, which represents a potential health risk for the dogs [61]. In California, morbidity and mortality of the southern sea otter, Enhydra lutris nereis (Linn.) were attributed to massive infections with $P$. altmani reaching 8760 worms per animal causing intestinal perforations, nutrient depletion, and mortality [49, 63]. Histopathological lesions in the intestine of another definitive host in Peru, the grey gull Leucophaeus modestus (Tschudi) were explored by Gonzales-Viera et al. [32].

The following are perspectives on available molecular findings of populations of $P$. altmani in South and North American Atlantic and Pacific coasts. Sequences of cystacanths of $P$. altmani collected from Emerita brasiliensis Schmitt in Uruguay produced 3 distinct haplotypes, suggesting that the "cystacanths recovered from E. brasiliensis on the southern Atlantic coast have low genetic variation and therefore belong to the same species, $P$. altmani, that has already been recorded on the Californian and Chilean Pacific coasts, as well as on the Atlantic coast of North America" [57]. Rodriguez et al. [59] concluded that haplotypes of $P$. altmani from Chile did not form a monophyletic group and clarified the role of environmental factors and host foraging behavior as determinants of predator-prey relationships. Goulding and Cohen [33] noted that sequences from COI and ITS loci revealed shared haplotypes between the North American east and west coast populations, indicating wide dispersal of this parasite.

Our work will contribute to the body of work that has been already reported by other observers of this acanthocephalan already known to have a wide host use and potential high impact on animal and even human populations. We shall supplement known morphology of this parasite with observations of newly observed structures using scanning electron micrographs and color optical micrographs, provide comparative morphometrical information, analyze the chemistry of hooks and spines for the first time, produce new molecular analysis from cystacanths from Peru, and produce new histopathological images from $L$. belcheri for the first time.

\section{Materials and methods Collections}

Specimens were deposited in the University of Nebraska's State Museum's Harold W. Manter Laboratory (HWML) collection, Lincoln, Nebraska, USA.

\section{Cystacanths}

In the spring (November to December) of 1976, about 200 specimens of the Pacific mole crab, Emerita analoga were collected in Playa Pescadores, Chorrillos $\left(12^{\circ} 10^{\prime} 00^{\prime \prime} \mathrm{S}-77^{\circ}\right.$ $\left.02^{\prime} 00^{\prime \prime} \mathrm{W}\right)$, Lima, Peru and fixed in ethanol. The prevalence was $80 \%$ and intensity was from 2 (in small crustaceans) to 20-30 (in large crustaceans). In the spring (September to October) of 1982; 558 specimens of E. analoga were collected from Playa Conchán, Lurin $\left(12^{\circ} 14^{\prime} 59^{\prime \prime} \mathrm{S}-76^{\circ} 56^{\prime} 15^{\prime \prime} \mathrm{W}\right)$, Lima. The prevalence was $65 \%$ and the intensity ranged from 1 (in small crustaceans) to 9 parasites (in large crustaceans).

\section{Adults}

In the spring (end of August) of 1981, 4 adult gulls, Larus belcheri from Pasamayo Beach $\left(11^{\circ} 49^{\prime} 41^{\prime \prime} \mathrm{S}-77^{\circ} 7^{\prime} 51^{\prime \prime} \mathrm{W}\right)$ were autopsied at the Ichthyology Laboratory (FOPCAUNFV). All the birds were heavily parasitized and it was difficult to extract the parasites from the packed intestine. In the spring (September) of 1982, 2 adult L. belcheri were captured alive at Punta Roquitas Beach, in the Miraflores District, Lima $\left(12^{\circ} 07^{\prime} 03^{\prime \prime} \mathrm{S}-77^{\circ} 02^{\prime} 35^{\prime \prime} \mathrm{W}\right)$ and were used to carry out experimental infections with 50 cystacanths each that yielded successful infections with juvenile and adult specimens of $P$. altmani.

Twenty-four cystacanths were whole mounted on slides that were made available for microscopical studies. Twenty cystacanths (13 males, 7 females) were studied and measured. The specimens were all fixed in ethanol and stained with Borax carmine. A total of 42 adults of $P$. altmani were collected from 4 Belcher's gulls, L. belcheri in Playa Pasamayo, Ancón $\left(11^{\circ}\right.$ $\left.49^{\prime} 41^{\prime \prime} \mathrm{S}, 77^{\circ} 7^{\prime} 51^{\prime \prime} \mathrm{W}\right)$, Lima northern beach, Peru, during 1981-1982. Sixteen Borax carmine-stained whole mounted specimens were made available and 5 males and 11 females were studied and measured, and the remaining were processed for microscopical studies to confirm species identification.

The Peruvian material also included 8 slides of hematoxylin-eosin-stained histopathological sections of adult specimens of $P$. altmani in $L$. belcheri intestinal sections that were initially fixed in formalin; 2 slides from each of the 4 heavily infected gulls in the spring of 1981 noted above. The edges of some slides showed signs of crystallization.

A similar collection of 10 cystacanths of Profilicollis botulus Van Cleave, 1916 were gathered from the lined shore crab, Pachygrapsus crassiceps Randall at Anaheim Beach, California $\left(33^{\circ} 41^{\prime} 34^{\prime \prime} \mathrm{N}-118^{\circ} 0^{\prime} 1^{\prime \prime} \mathrm{W}\right)$, of which 5 specimens were sequenced to include in a phylogenetic analysis; remaining specimens were processed for microscopical confirmation of species identification. From California, about 10 cystacanths of $P$. altmani were collected from the body cavity of specimens 
Table 3. Morphometrics of adults of Profilicollis altmani from Peru, Chile, the USA.

\begin{tabular}{|c|c|c|c|c|}
\hline \multirow[t]{2}{*}{ Study site } & \multicolumn{2}{|c|}{ Peru } & \multirow{2}{*}{$\begin{array}{c}\text { Chile } \\
\text { Caleta Lenga }\end{array}$} & \multirow{2}{*}{$\begin{array}{c}\text { USA } \\
\text { San Francisco }\end{array}$} \\
\hline & Pasamayo, Lima & Ancỏn, Lima & & \\
\hline Host & Larus belcheri & Larus belcheri & Larus pipixcan & Catoptrophorus semipalmatus ${ }^{* *}$ \\
\hline Source & Mateo et al. (1982)* & This study & Riquelme et al.(2006)* & Karl (1967) \\
\hline Sample size & 34 specimens & $5 \mathrm{MM}, 11 \mathrm{FF}$ & $9-16$ specimens & 10MM, 10FF \\
\hline \multicolumn{5}{|l|}{ Males } \\
\hline Total body length & $15,600-16,400(15,800)^{* * *}$ & $12,750-16,000(14,500)$ & $6000-21,700(14,400)$ & $8500-16,600(12,700) * * * *$ \\
\hline Trunk length & - & $9375-12,000(10,475)$ & $4500-13,500(11,100)$ & $9800-14,170(11,660)$ \\
\hline Trunk width & $1610-1850(1700)$ & $1250-2450(1775)$ & $1000-2000(1300)$ & $1510-3000(2200)$ \\
\hline Proboscis shape & Spheroid & Spheroid & Spheroid & Spheroid \\
\hline Proboscis length & - & $1025-1125(1150)$ & $500-1700(1100)$ & $630-1220(780)$ \\
\hline Proboscis width & $1500-1870(1660)$ & $1200-1575(1415)$ & - & $710-1230(800)$ \\
\hline Rows of hooks & $27-33$ & $25-36(30)$ & $24-30(28)$ & $23-30(27)$ \\
\hline Hooks/row & $13-15$ & $11-13(12)$ & $13-15(14)$ & $10-15(13)$ \\
\hline \multicolumn{5}{|l|}{ Length of hooks } \\
\hline Apical & 44 & $38-42(39)$ & - & $30-50(40)$ \\
\hline Middle & 33.5 & $37-43(39)$ & - & $30-60(50)$ \\
\hline Basal & 54.7 & $50-58(53)$ & - & $40-60(50)$ \\
\hline Receptacle length & $5740-7320(6170)$ & $4125-5750(5285)$ & $1200-2600(2400)$ & 1910-3510 (2610) \\
\hline Receptacle width & $460-530(490)$ & 287-500 (417) & - & $310-740(530)$ \\
\hline Neck length & 2830-3430 (3150) & 2375-3050 (2770) & $1000-3000(2100)$ & 1360-2310 (1810) \\
\hline Neck width & $430-480(460)$ & $350-575(465)$ & $200-500(300)$ & $310-490(430)$ \\
\hline Lemnisci length & $2780-3600(3100)$ & $2025-2925$ (2667) & $1300-4000(2400)$ & $1430-2400(1610)$ \\
\hline Lemnisci width & $290-360(330)$ & $275-500(417)$ & - & - \\
\hline \multicolumn{5}{|l|}{ Trunk spines } \\
\hline Rows of spines & - & $30-36(32)$ & - & 25-30 \\
\hline Spines/row & - & $21-23(22)$ & - & $10-16$ \\
\hline Spine length & - & $25-30(28)$ & - & - \\
\hline Anterior testis length & $960-1390(1200)$ & $850-1200(1055)$ & 300-1.700 (0.800) & $410-1110(670)$ \\
\hline Anterior testis width & $650-960(790)$ & $600-800(670)$ & $100-800$ (400) & $390-1010(560)$ \\
\hline Posterior testis length & $1032-1390(1250)$ & 875-1200 (1055) & 200-1600 (800) & $410-1110(670)$ \\
\hline Posterior testis width & $670-960(800)$ & $488-700(628)$ & $100-800(\mathbf{4 0 0})$ & $390-1010(560)$ \\
\hline Cement gland length & $5520-6500(5950)$ & $3375-5250(4134)$ & $200-600(300)$ & $4000-5400$ \\
\hline Cement gland width & $90-150(120)$ & 65-150 (111) & - & - \\
\hline Bursa length & 720 (average) & $750-800(775)$ & - & $750-1100(890)$ \\
\hline Bursa width & 720 (average) & $750-825$ (787) & - & $600-890(630)$ \\
\hline \multicolumn{5}{|l|}{ Females } \\
\hline Total body length & $16,500-21,600(19,400)$ & $10,000-23,000(15,053)$ & $10,700-28,500(18,400)$ & $10,700-18,400(15,400)$ \\
\hline Trunk length & - & $6875-18,875(11,267)$ & $8000-18,500(13,800)$ & $9800-14,170(11,660)$ \\
\hline Trunk width & 1560-1990 (1790) & $1175-2200(1602)$ & 900-1700 (1800?) & $1920-2630(2310)$ \\
\hline Proboscis shape & Spheroid & Spheroid & Spheroid & Spheroid \\
\hline Proboscis length & - & $675-1375(956)$ & $500-2000(1200)$ & $630-1220(780)$ \\
\hline Proboscis width & 1540-1910 (1710) & 750-1575 (1127) & $600-2000(1300)$ & $710-1230(800)$ \\
\hline Rows of hooks & $27-33$ & $30-34(32)$ & 28-31 (29) & $23-30(27)$ \\
\hline Hooks/row & 13-15 (usually 15) & $11-16(13)$ & $13-17(14)$ & $10-15(13)$ \\
\hline \multicolumn{5}{|l|}{ Length of hooks } \\
\hline Apical & 44 & $35-45(38)$ & - & $30-50(40)$ \\
\hline Middle & 33.5 & $38-42(39)$ & - & $30-60(50)$ \\
\hline Basal & 54.7 & $48-60(55)$ & - & $40-60(50)$ \\
\hline Receptacle length & $6480-6720(6600)$ & $4000-6500(5539)$ & $1100-4400(3100)$ & $1910-3510(2610)$ \\
\hline Receptacle width & $480-550(520)$ & 200-550 (339) & - & $310-740(530)$ \\
\hline Neck length & $2780-4200(3490)$ & 1875-3825 (2953) & $600-4000(2500)$ & $1360-2310(1810)$ \\
\hline Neck width & $380-550(470)$ & $425-625(528)$ & $300-600(400)$ & $310-490(430)$ \\
\hline Lemnisci length & $3000-3890(3460)$ & 1750-3755 (2603) & $2500-5200(2600)$ & 1430-2400 (1610) \\
\hline Lemnisci width & $312-530(380)$ & $150-525(336)$ & - & - \\
\hline \multicolumn{5}{|l|}{ Trunk spines } \\
\hline Rows of spines & - & $38-54(47)$ & - & 25-30 \\
\hline Spines/row & - & $23-34(28)$ & - & 10-16 \\
\hline Spine length & - & $22-30(26)$ & - & - \\
\hline Reproductive system length & 5990 & $3675-8500(5930)$ & - & - \\
\hline
\end{tabular}


Table 3. (Continued)

\begin{tabular}{|c|c|c|c|c|}
\hline \multirow[t]{2}{*}{ Study site } & \multicolumn{2}{|c|}{ Peru } & \multirow{2}{*}{$\begin{array}{l}\text { Chile } \\
\text { Caleta Lenga }\end{array}$} & \multirow{2}{*}{$\begin{array}{c}\text { USA } \\
\text { San Francisco }\end{array}$} \\
\hline & Pasamayo, Lima & Ancỏn, Lima & & \\
\hline Host & Larus belcheri & Larus belcheri & Larus pipixcan & Catoptrophorus semipalmatus** \\
\hline Source & Mateo et al. (1982)* & This study & Riquelme et al.(2006)* & Karl (1967) \\
\hline Sample size & 34 specimens & $5 \mathrm{MM}, 11 \mathrm{FF}$ & 9-16 specimens & $10 \mathrm{MM}, 10 \mathrm{FF}$ \\
\hline Egg length & $65.8-75.9(71.3)$ & $52-60(57)$ & $50-70(60)$ & $60-70(65)$ \\
\hline Egg width & $24.0-37.6(27.7)$ & $16-23(19)$ & $20-20(20)$ & $22-30(26)$ \\
\hline
\end{tabular}

* Described as Polymorphus (Profilicollis) bullocki.

** Karl (1967) reported 8 species of shore birds of California naturally infected with $P$. altmani, with $C$. semipalmatus being the most heavily infected species. His morphometrics were based on emended description of specimens obtained from his heavily infected experimental hosts, the duckling Anas platyrhynchus Linn. Common measurements of proboscis, hooks, neck, spine, receptacle and lemnisci were the same for both sexes.

*** Range (mean) in micrometers.

***** Bolded figures indicate atypically smaller measurements or counts.

of E. analoga at Redondo Beach $\left(33^{\circ} 51^{\prime} 29^{\prime \prime} \mathrm{N}-118^{\circ}\right.$

$\left.22^{\prime} 44^{\prime \prime} \mathrm{W}\right)$. Five specimens were used for molecular studies.

Genetic comparison and phylogenetic analyses were based on a fragment of $645 \mathrm{bp}$ of the mitochondrial cytochrome oxidase I (COI) gene of one sequence of a $P$. altmani specimen. Details of these analyses are provided in Supplementary Material. Briefly, the new COI sequence was aligned to a matrix with one representative of each haplotypic class of Profilicollis altmani, P. chasmagnathi, P. novaezelandensis, and $P$. botulus from diverse intermediate and definitive hosts $[29,30,33,34,46,57,59,60]$ available in GenBank. As such, a total of 24 sequences of Profilicollis were analyzed (Table S1). In addition, sequences of Polymorphus minutus and Arhythmorhynchus brevis were used to form the outgroup. Sequence alignment and observed genetic distances $(p)$ were done and calculated in MEGA 7 [68]. Finally, two methods of phylogenetic inference were implemented, maximum likelihood (ML), which was conducted with IQ-TREE, and Bayesian inference (BI) conducted with MrBayes 3.1 $[62,72]$ (see details in Supplemental Material).

\section{Comparative material}

Figures in all previous descriptive accounts were only created in line drawings that we are not duplicating. We are referring interested parties to original line-drawings in the following descriptions. The first description by Perry [54] (page 387) included 4 line-drawings of a whole male with spherical testes, anterior end of a female, part of a middle section of a proboscis not showing hook roots, and an egg. Van Cleave's [75] description of $P$. kenti, included 2 line-drawings of a praesoma and of half a proboscis not showing hook roots (pages 305, 309). Webster's [77] description of $P$. texensis included 6 line-drawings (page 67) of a male, a female, a few rooted hooks, spines, and 2 eggs. In their description of $P$. bullocki, Mateo et al. [47] provided line drawings in 5 figures of a male, female reproductive system, rooted hooks nos. 1, 4, 5, 14, and eggs (page 5). Mateo et al. [48] also included 2 line-drawings of a male cystacanth and a proboscis. Karl [42] provided many line-drawings of males and females (Figs. 1-8, page 83-87), developing proboscides (Figs. 9-11, page 89), young adults (Figs. 22-23, page
99-101), and male and female cystacanths (Figs. 18, 21, page 95-97). All line-drawings of this acanthocephalan species by other and subsequent observers are only renditions of one or more in the above quoted accounts.

\section{Optical microscope images}

Optical microscope images were acquired using a BH2 light Olympus microscope (Olympus Optical Co., Osachi-shibamiya, Okaya, Nagano, Japan) attached to an AmScope 1000 video camera (United Scope LLC, dba AmScope, Irvine, CA, USA), linked to an ASUS laptop equipped with HDMI highdefinition multimedia interface system (Taiwan-USA, Fremont, CA, USA). Images from the microscope are transferred from the laptop to a USB and stored for subsequent processing on a computer.

\section{Scanning electron microscopy (SEM)}

About 15 specimens that had been fixed and stored in $70 \%$ ethanol were processed for SEM following standard methods [44]. These included critical point drying (CPD) (Tousimis Automandri 931.GL) and mounting on aluminium SEM sample mounts (stubs) using conductive double-sided carbon tape. Samples were sputter coated with an 80-20\% gold-palladium target for 3 minutes using a sputter coater (Quorum (Q150T ES) www.quorumtech.com) equipped with a planetary stage, depositing an approximate thickness of $20 \mathrm{~nm}$. Samples were placed and observed in an FEI Helios Dual Beam Nanolab 600 (FEI, Hillsboro, OR, USA) Scanning Electron Microscope (FEI). Samples were imaged using an accelerating voltage of $5 \mathrm{kV}$, and a probe current of $86 \mathrm{pA}$, at high vacumm using an SE detector.

\section{Focused Ion Beam (FIB) sectioning of hooks}

A dual-beam SEM with gallium (Ga) ion source (GIS) was used for the LIMS (Liquid Ion Metal Source) part of the process. The gallium beam (LIMS) is a gas injection magnetron sputtering technique whereby the rate of cutting can be 

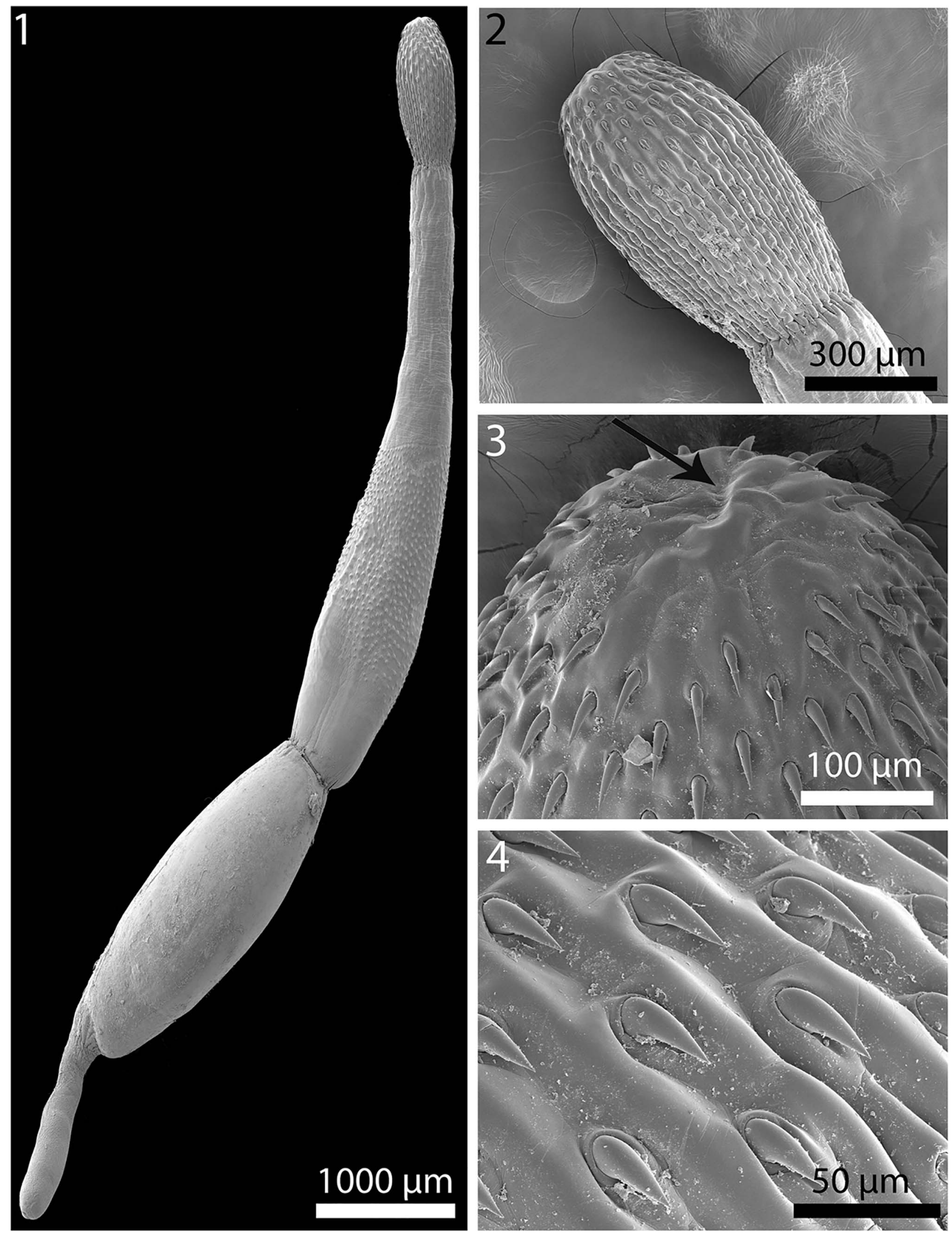

Figures 1-4. SEM of cystacanths of Profilicollis altmani from Emerita analoga on the Peruvian coastline, Lima. 1. Entire female cystacanth showing proboscis, neck and trunk regions. 2. Entire proboscis. 3. An apical view of proboscis with external evidence of an apical organ (arrow). 4. Mid-part of proboscis with hooks embedded in furrows. 

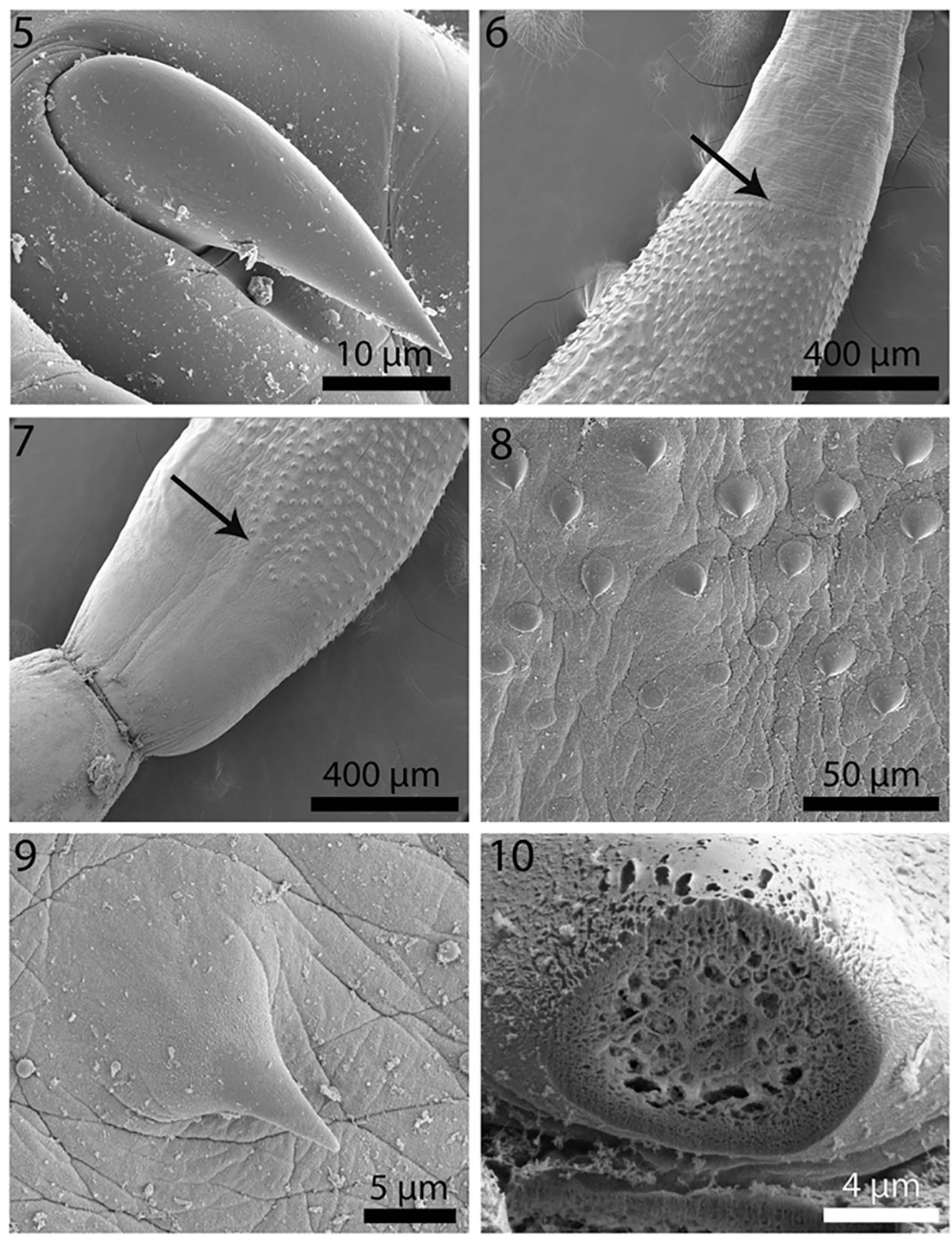

Figures 5-10. SEM of cystacanths of Profilicollis altmani from Emerita analoga on the Peruvian coastline, Lima. 5. A robust hook in the mid-section of a proboscis with thick base. 6. The posterior part of the neck interface with the anterior spinose trunk of a cystacanth. Note anterior spines in perfect ring (arrow). 7. The posterior part of anterior trunk section showing the incomplete spination posteriorly (arrow). 8. More posterior trunk spines are occasionally in irregular circles randomly distributed. 9. A high magnification of a trunk spine showing cross serrations of cuticular surface. 10. A Gallium cut section of a trunk spine showing its spongy center and denser cortical layer. 

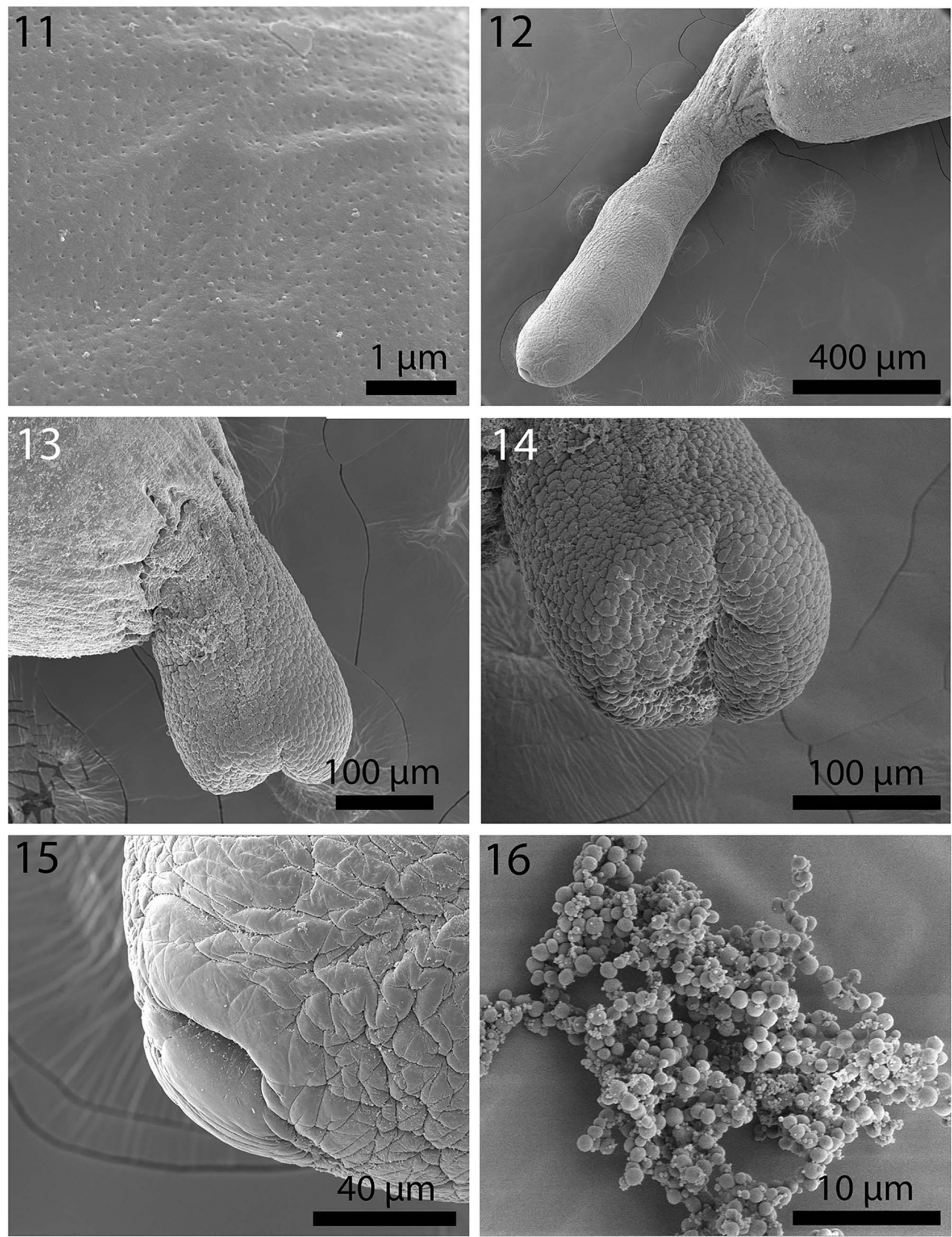

Figures 11-16. SEM of cystacanths of Profilicollis altmani from Emerita analoga on the Peruvian coastline, Lima. 11. Micropores from the mid-trunk region. 12. A fully extended tail. 13. Lateral view of a partially retracted tail. 14. Posterior view of the partially retracted tail showing invagination point and the coarse corrugated texture of the cuticular surface. 15. Genital orifice of a female gonopore at the posterior end of a fully extended tail. Note the thick un-corrugated lips. 16. A cluster of developing eggs in a female cystacanth. 

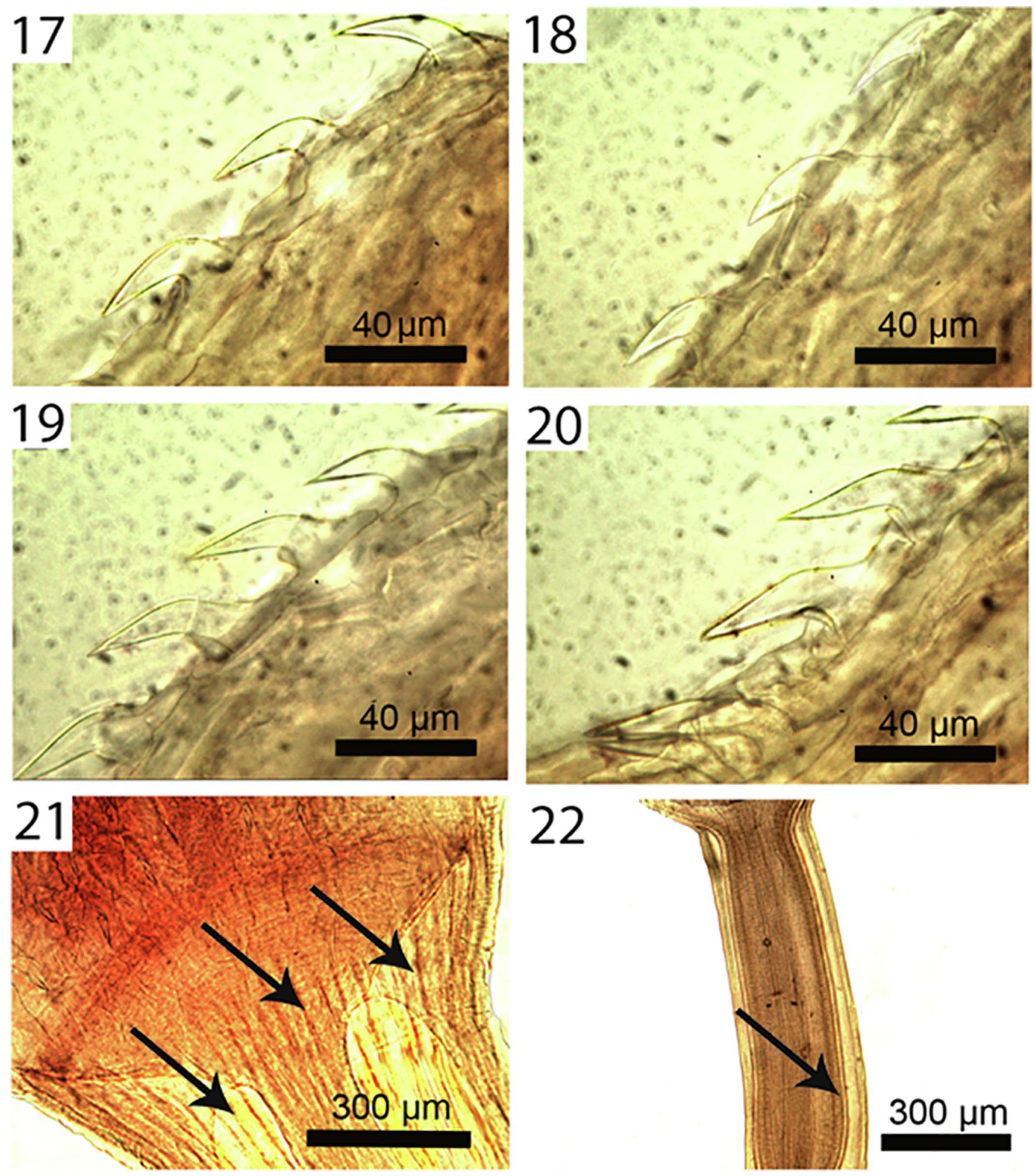

Figures 17-22. Micrographs of cystacanths and adults of Profilicollis altmani from Emerita analoga and from Larus belcheri, respectively on the Peruvian coastline, Lima. 17-20. Lateral views of hooks and roots of one longitudinal row on the proboscis of a cystacanth. 17. Apical and 2 subapical hooks and roots. 18. Hook nos. 4, 5, and 6 with their roots. Note the shorter and thickest hook no. 5 (at middle). 19. Hook nos. $7-$ 10; note the increasing size of hooks posteriorly. 20. Hook nos. 11-15. Note the increasing size of hooks posteriorly being longest and more crowded basally. 21. Fan shaped anterior end of proboscis receptacle inserted at the posterior end of the proboscis. Note the heavy muscular fibers of the neck (arrows). 22. Double-walled proboscis receptacle (arrow) within the neck of an adult specimen directly posterior to attachment to proboscis. 

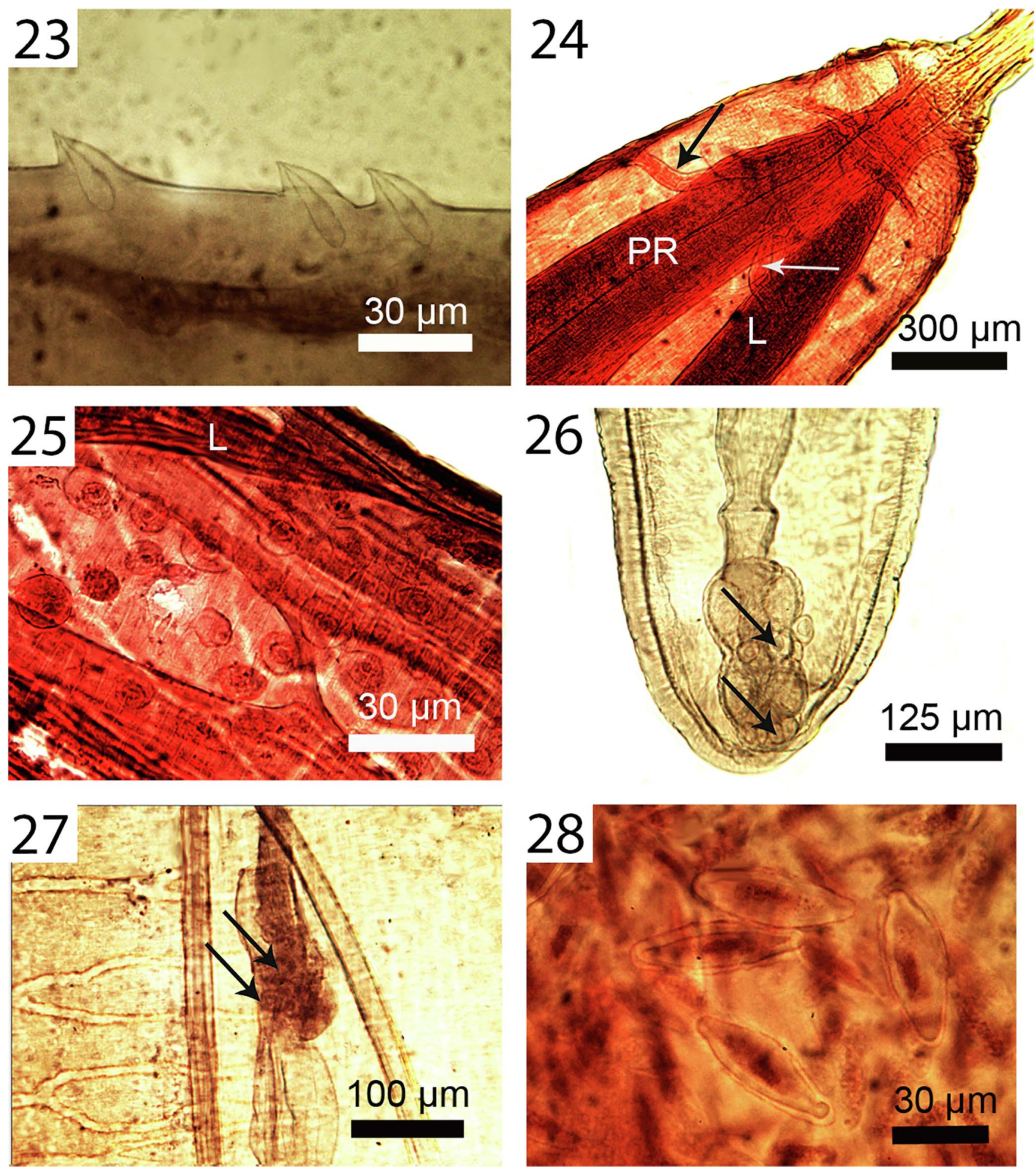

Figures 23-28. Micrographs of adult females of Profilicollis altmani from Larus belcheri, on the Peruvian coastline, Lima. 23. Lateral view of trunk spines showing their single drop-shaped core support structure. 24. Anterior end of a specimen showing the 2 lateral retinacular nerves (arrow), the proboscis receptacle (PR) and a lemniscus (L). 25. Anterior trunk showing the prominent branching longitudinal muscle fibers and the hypodermic nucleated cells in the area of the fibrillar attachment of a lemniscus (L) to the body wall. 26. Posterior part of a female reproductive system showing the near terminal position of the gonopore and the characteristic 4 horizontal nucleated cells at the posterior end of the vagina and between the sphincters (arrows). 27. Simple, thin-walled uterine bell with few small nucleated uterine bell cells (arrows). Note part of the reticular lacunar system (left) and median ligaments. 28. Eggs. Note the thick outer shell and the polar prolongation of the fertilization membrane. 
regulated. The hooks were sectioned at two positions (tip and middle) using the FEI Helios Dual Beam Nanolab mentioned above. The dual-beam FIB/SEM is equipped with a gallium (Ga) Liquid Ion Metal Source (LIMS). The hooks of the acanthocephalans were centered on the SEM stage and crosssectioned using an ion accelerating voltage of $30 \mathrm{kV}$ and a probe current of $2.7 \mathrm{nA}$, following the initial cut. The time of cutting is based on the nature and sensitivity of the tissue. The sample also goes through a cleaning cross-section milling process to obtain a smoother surface. The cut was analyzed with an X-ray normally at the tip, middle, and base of hooks for chemical ions with an electron beam (Tungsten) to obtain an X-ray spectrum. The intensity of the GIS was variable according to the nature of the material being cut. Results were stored with the attached imaging software then transferred to a USB for future use.

\section{Energy Dispersive X-ray analysis (EDXA)}

The Helios Nanolab 600 is equipped with an EDXA (Mahwah, NJ, USA) TEAM Pegasus system with an Octane Plus detector. The sectioned cuts were analyzed by EDXA. Spectra of selected areas were collected from the center and the edge of each cross-section. EDXA spectra were collected using an accelerating voltage of $15 \mathrm{kV}$, and a probe current of $1.4 \mathrm{nA}$. Data collected included images of the displayed spectra as well as the raw collected data. Relative elemental percentages were generated by TEAM software.

\section{Histopathology}

For the histological sections, heavily infected intestinal tissues of L. belcheri collected from Playa Pasamayo, Ancón, Lima in 1981 were fixed in $10 \%$ buffered formalin. After dehydration and embedding in paraffin, the specimens were processed using standard methods comparable to those of Kiernan [43] and Bancroft and Gamble [22]. These paraffin tissue blocks were sectioned at 4-6 microns, placed on glass slides and stained with hematoxylin and eosin (HE). The prepared glass slides were viewed with a $\mathrm{BH} 2$ light Olympus microscope (Olympus Optical Co., Osachi-shibamiya, Okaya, Nagano, Japan); see Microscope Images above.

\section{Results}

The following treatment is based on the microscopic and SEM studies of cystacanths and adults of $P$. altmani collected from E. analoga and L. belcheri, at various beaches of Lima, Peru during 1976-1978 and 1981-1982, respectively. We note that the prevalence and intensity of infection of E. analoga with cystacanths decreased from $80 \%$ and 2-30 in 1976 to $65 \%$ and 1-9 in 1981. The microscopical study provided considerable new detail not known in the previous descriptions under the various names of this common acanthocephalan. The SEM studies added considerable new detail as this species was not previously studied with SEM.

The following parasite descriptions will be in 2 sections: cystacanths and adults.

\section{Cystacanths}

One descriptive account of cystacanths based on 7 cystacanths studied with SEM (Figs. 1-16) and on 20 cystacanths (13 males and 7 females) measured and studied with microscopic images (Figs. 17-36) from whole mounts obtained from E. analoga in Peru is provided below.

Description of cystacanths from $E$. analoga from Peru. (structures not previously reported are bolded)

With characters of the family Polymorphidae and genus Profilicollis. Body flattened dorso-ventrally, divided by constrictions into proboscis, long cylindrical neck, spinose trunk, ovoid hindbody, and tail of variable length that may be partially or wholly retracted (Fig. 1). See comparative measurements and counts in Table 1. Proboscis ovoid with flattened anterior end showing evidence of apical organ and indented longitudinal rows of at least 13 hooks each (Figs. 2-3). Hooks of similar shape (Fig. 4), increasing in length and diameter from apical to fourth hook. Fifth hook abruptly shorter but thickest, 6th hook, smallest; hooks gradually increasing in size posteriorly to maximum basally (Figs. 17-20). Complete measurements of hooks in 1 longitudinal row in Table 2. All hooks with gradually thickening base (Fig. 5), rooted with prominent anterior manubria (Figs. 17-20). Hook tips with high level of sulfur and low levels of phosphorous and calcium and midhook showing opposite trend. Neck long (Fig. 22) widening at base. Proboscis receptacle evident through neck extending to about half length of spinose trunk. Trunk with many electron-dense micropores (Fig. 11) and incipient hypodermic nucleated cells (Fig. 34). Anterior trunk with irregular circles of spines ending anterior to trunk constriction (Fig. 8). Spines pointed with broad base, dense cortical layer and spongy core (Figs. 9, 10). Anterior and middle spines with higher level of calcium than phosphorous and sulfur but posterior spines with low levels of all elements. Lemnisci variable in length occasionally extending beyond or shorter than receptacle. Posterior tail with corrugated texture, often extended (Fig. 12) but occasionally partially retracted (Figs. 13, 14). Incipient testes spheroid to ovoid, often in spiny trunk region or occasionally in hind body (Fig. 34) where trunk may contain developing cement glands and barely distinguishable invaginated vestigial bursa. In female cystacanths, parts of developing reproductive system relatively visible (Fig. 35) with proximal genital ducts developing as invagination of body wall (Fig. 36) and terminal gonopore with bulbous lips occasionally prominent (Fig. 15) and developing eggs occasionally observed (Fig. 16).

\section{Taxonomic summary}

Host: Pacific mole crab, Emerita analoga (Stimpson) (Crustacea: Hippidae).

Other hosts: See other hosts in Table 1.

Site of infection: Body cavity.

Locality: Playa Pescadores, Chorrillos $\left(12^{\circ} 10^{\prime} 00^{\prime \prime} \mathrm{S}\right.$, $\left.77^{\circ} 02^{\prime} 00^{\prime \prime} \mathrm{W}\right)$, Lima, Peru.

Other localities: See other localities in Table 1, including the Pacific and Atlantic coasts of North and South America.

Specimens: Cystacanths in HWML Parasitology Collection n. 216672 . 

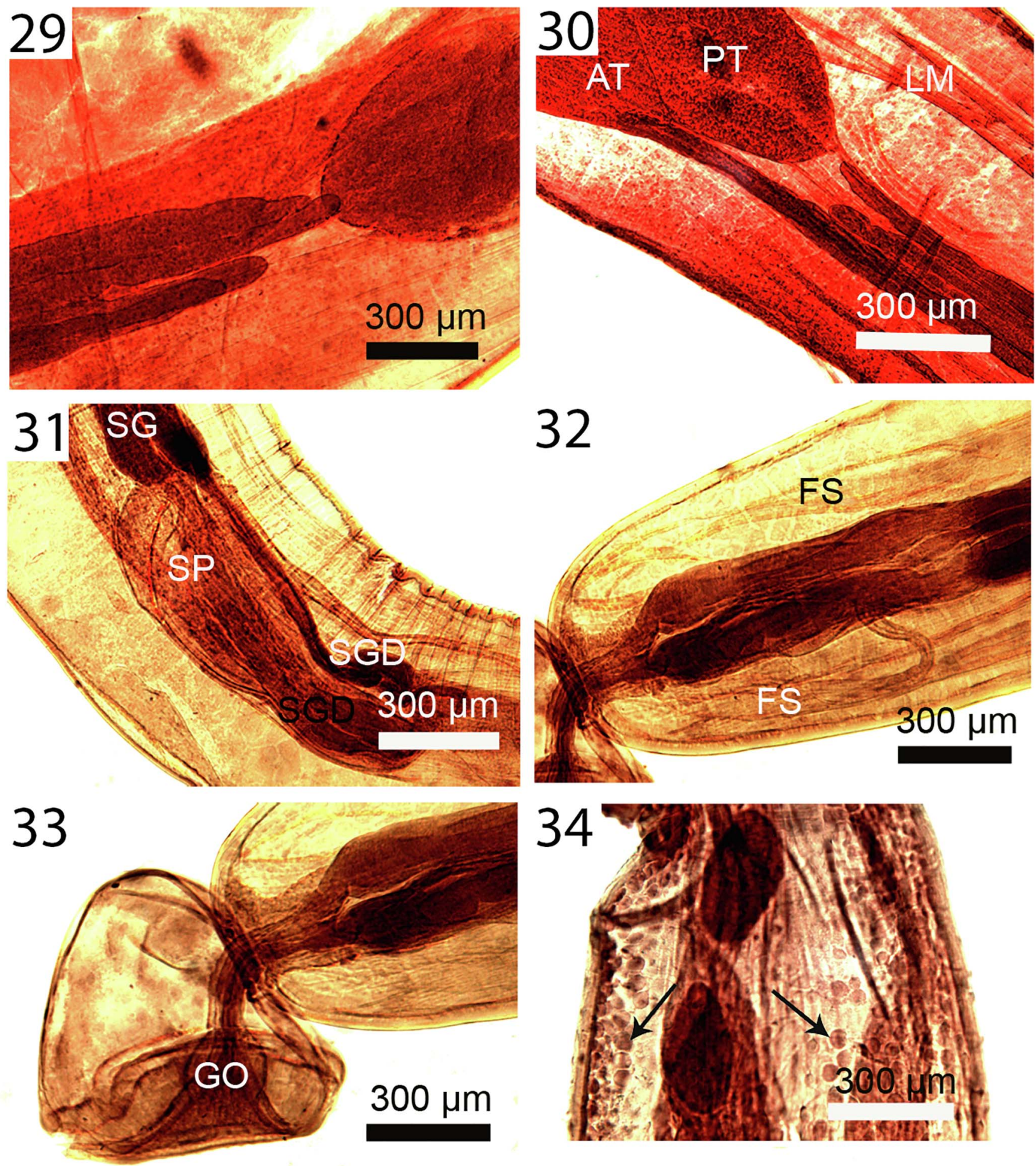

Figures 29-34. Micrographs of adult males of Profilicollis altmani from Larus belcheri (Figs. 29-33) and male cystacanth (Fig. 34) from Emerita analoga on the Peruvian coastline, Lima. 29. Anterior end of the 4 tubular cement glands interfacing with the posterior testis. Note that the unequal cement glands do not extend equally anteriorly. 30. Another example of extreme unequal anterior extension of cement glands to mid-point of posterior testis (PT) reaching anterior testis (AT). Note prominent longitudinal trunk muscles (LM). 31. Posterior part of a male reproductive system showing posterior end of cement glands (CG), cement gland duct (CGD), and Saefftigen's pouch (SP). 32. A pre-bursal perspective showing independent cement glands' ducts and associated fibral strands (FS). 33. The bell-shaped bursa with the cement gland's ducts channeling into the genital orifice (GO). No sensory structures were observed. 34. Developing testes in a cystacanth posterior to the second body constriction. Note the early stages of the hypodermic cells (arrows) throughout that are more developed in adults in Figure 27. 


\section{Remarks}

Line-drawings of $P$. altmani cystacanths have rarely been presented except for those included in Karl [42]; our SEM and microscopic images show details presented here for the first time. Previously, only Nickol et al. [53] presented a photograph of the praesoma of a cystacanth and Balboa et al. [21] included an SEM of the apical end of a proboscis of the same species. Our newly observed details include all proboscis hooks and roots, trunk spine arrangement and anatomy, tail, emerging eggs and female gonopore. We also note the presence of micropores described here for the first time in cystacanths in any species of acanthocephalans; micropores have been previously described from adults only.

Our specimens had larger proboscides than in others reported from E. analoga in Peru by Mateo et al. [48] but smaller than those from the same host species in Chile by Balboa et al. [21] (Table 1). Our specimens had a rather wide variation in the number of hook rows (26-34) and number of hooks per row (13-16), respectively, relative to cystacanths in all other collections especially those from North Carolina (28 and 12) except those studied by Karl [42] who reported 21-35 rows of 10-15 hooks each (Table 1). The specimens from Chile and Uruguay had the largest size hooks compared to those from other collections in Peru and the United States. The proboscis receptacle was smallest in cystacanths from E. brasiliensis in Uruguay and those from E. talpoida in North Carolina. The lemnisci reached maximum length in our cystacanths from E. analoga in Peru with comparable average values in all collections. All above differences fall within the range of intraspecific variability and extremes may be related to host species and geography.

\section{Adults}

Description of adults from $L$. belcheri in Peru (structures not previously reported are bolded).

General. With character of Polymorphidae, genus Profilicollis. Shared structures larger in males than in females. Body elongate, cylindrical, divided by two mild constrictions into three distinct regions of about equal length, with the middle part being widest. See measurements and counts in Table 3. Proboscis spheroidal but occasionally oblate especially in older adults. Hooks, like those of cystacanths, similar in shape (Fig. 4) increasing in length and diameter from apical to fourth hook; fifth hook abruptly shorter but thickest, 6th hook, smallest, gradually increasing in size posteriorly to maximum basally (Table 2). All hooks rooted with prominent anterior manubria (see Figs. 17-20) as in cystacanths. Neck slender, somewhat cylindrical (Fig. 22) and widest posteriorly at junction with trunk. Trunk walls with numerous small hypodermic nucleated cells (Fig. 25) and reticular lacunar system (Fig. 27). Anterior trunk tapering towards the neck with complete circles of spines similar to those of cystacanths. Spines pointed with broad base, elongate drop-shaped single-core rod support (Fig. 23) and denser cortical layer. Posterior region of trunk tapers towards posterior end with terminal gonopores in both sexes. Proboscis receptacle double-walled, fan-like anteriorly, arising at base of spheroid proboscis (Fig. 21), about twice as long as neck. Two prominent complex retinacular nerves emerging from cephalic ganglion slightly posterior to level of anterior trunk and passing through receptacle walls before entering into circular and longitudinal muscle layers of body wall (Fig. 24). Lemnisci (Fig. 24) not always equal and vary in length appearing shorter or longer than receptacle, and attached to body wall by posterior fibrils at level of first trunk constriction.

\section{Males}

Testes spheroid to ovoid, about equal, contiguous, preequatorial. Four unequal, tubular cement glands usually terminating anteriorly at different levels occasionally reaching or overlapping posterior testis (Figs. 29-30). Four cement gland ducts emerging independently from cement glands posteriorly to join at juncture into bursa (Figs. 31-33). Prominent fibers and filaments appearing to connect cement gland ducts with posterior end of trunk from where others extending anteriorly (Fig. 32). Bursa bell-shaped with conspicuous but reduced rays and without apparent sensory structures (Fig. 33).

\section{Female}

Reproductive system $40 \%$ length of trunk with welldefined vagina, 2 sphincters, very long uterus, and small thin-walled uterine bell (UB) with few small nucleated UB cells (Fig. 27). Four prominent horizontal nucleated cells at base of vagina and 4 more between sphincters (Fig. 26). Eggs fusiform with outer membrane appearing of hyaline components and inner membranes of fibrillar nature and with slight polar prolongation of fertilization membrane (Fig. 28).

\section{Taxonomic summary}

Host: Belcher's gull, Larus belcheri (Vigors) (Aves: Laridae).

Other hosts: Melanitta perspicillata (Linn.) (type), M. deglandi (Bonaparte) (see Perry, [54]), Larus argentatus Pontoppidan (see Van Cleave, [75]), Crocethia alba (Pallas) (see Webster, [77]). Also see other hosts in Table 3 and the following 4 hosts listed by Riquelme et al. [56] from Chile: Larus pipixcan (Wagler), L. dominicanus Lichtenstein, Numenius phaeopus (Lin.), and Podiceps occipitalis Garnot. The other following 5 host species were also listed among 8 species recorded by Karl [42] from California: Catoptrophorus semipalmatus (Gmelin), Cerorhinca monocerata (Pallas), Marila affinis (Eyton), Pelidna alpina (Linn.), and Phaeopus hudsonicus (Latham).

Locality: Playa Pasamayo, Ancón (11 49'41" S, $77^{\circ} 7^{\prime} 51^{\prime \prime} \mathrm{W}$ ), Lima northern beach, Peru.

Other localities: See other localities in Table 3, among others along the Pacific and Atlantic coastlines of North and South America.

\section{Remarks}

The adult populations of $P$. altmani compared in Table 3 show intraspecific variations that may be related to host species 

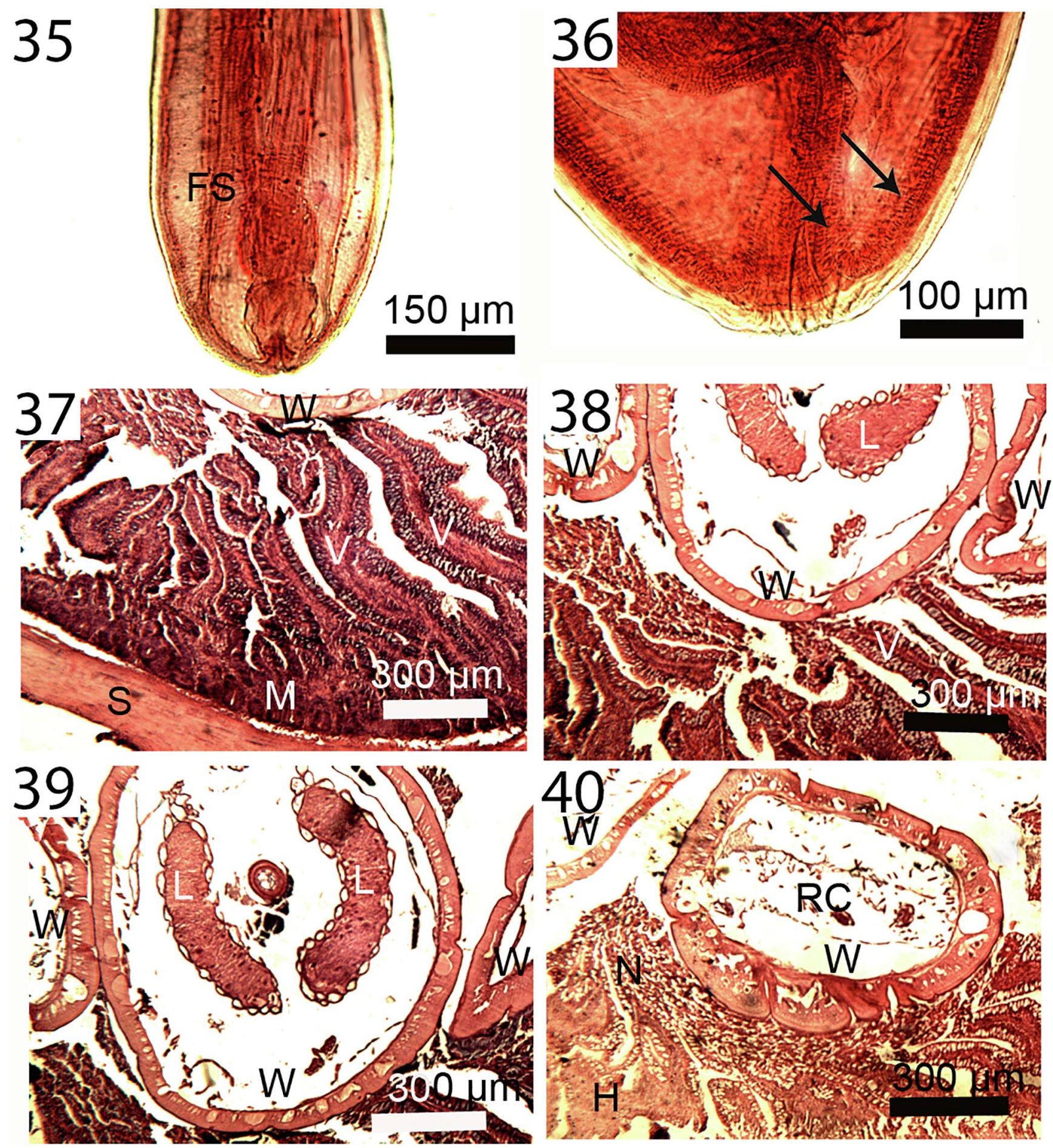

Figures 35-40. Micrographs of cystacanths (Figs. 35, 36) and adults in histopathological sections (Figs. 37-40) of Profilicollis altmani from Emerita analoga and Larus belcheri, respectively. 35. Posterior portion of the incipient female reproductive system of a cystacanth. Note the two sets of lateral para-vaginal fibrillar strands; left bundle marked (FS). 36. Terminal gonopore and the developing proximal portion of a female system in another cystacanth. Note the body wall layers invaginating into the barely visible reproductive system ducts (arrows). 37. A section showing the serosa (S) of the host intestine and the mucosa and submucosa (M) with disruption of the villi (V) near the worm (W) interface. 38. Crowding effect in this heavily infected host gut is evident with parts of these 3 worms (W) totally destroying the tips of the villi (V). The lemnisci (L) of the worm in the center are prominent. 39. A different perspective of a section in another heavy infection with 3 worms (W) with the central worms featuring both lemnisci (L) with corrugated surface epithelium. Note the destruction of the tips of the villi (V) and its disintegration into necrotic tissue $(\mathrm{N})$. 40. A worm $(\mathrm{W})$ in a different section of the host gut showing various types of destruction and disorientation of the mucosal layers, formation of necrotic tissue $(\mathrm{N})$ and hemorrhaging $(\mathrm{H})$. Reproductive cells $(\mathrm{RC})$ continue to be produced in worms (females) (W) at that stage of infection. 
or geography. The 2 populations from L. belcheri from 2 different geographical locations along the Lima coastal line in Pasamayo and Ancon display the following variations. Our specimens from Ancon had smaller receptacle, neck, and lemnisci in both sexes, smaller testes and cement glands, and smaller eggs than specimens collected from the same host species from Pasamayo in the original description by Mateo et al. [47] (Table 3). Variations in size, especially when marked in certain structures, may be attributable geographical factors, assuming that host populations in these 2 collection sites do not mix.

Specimens from L. pipixcan in Chile (Table 1) had markedly smaller receptacle and neck in both sexes compared to those from both collections in Peru from L. belcheri, as well smaller mean testes measurements and considerably smaller cement gland length. The latter cement gland length measurement of 200-600 (300) from Chile [56] (page 468) is unreasonable and could not be verified by figures or other descriptions but was comparable to other measurements varying between 100 and 600 from 3 other sympatric host species (L. dominicanus, Numenius phaeopus, Podiceps occipitalis) examined by the same authors from Chile (their Table 1). Similarly, specimens from Catoptrophorus semipalmatus from California exhibit smaller size body, proboscis neck, neck, and lemnisci length in both sexes as well as number of trunk spines compared to specimens from Peru (Table 3). It is hard to compare Karl's [42] specimens from California with others from elsewhere because he did not account for morphometric differences and counts of shared structures between sexes.

\section{Molecular analyses}

Molecular analyses showed both phylogenetic trees gathered via ML and BI were mostly congruent ((Fig. S1). The sequence of the cystacanth recovered from a specimen of $E$. analoga collected at Redondo Beach, California falls in the P. altmani clade ( $\mathrm{PP}=0.89$; $\mathrm{BS}=100$; (Fig. S1). Within this clade of $P$. altmani, no monophyletic group per geographic region or host is formed (see also [33, 46, 57, 59, 60]). Haplotypes of $P$. altmani show low genetic variation (average $=1.2 \%$ ). Profilicollis altmani is sister to $P$. botulus $(\mathrm{PP}=1$; $\mathrm{BS}=88)$; both species differ on average by $15 \%$. The average genetic $p$-distance between the clades of $P$. altmani and $P$. botulus was 0.47 . $P$. chasmagnathi and $P$. novaezelandensis are sister to each other $(\mathrm{PP}=1$; $\mathrm{BS}=100)$. The average genetic $p$-distance between the clades of $P$. altmani and $P$. chasmagnathi was 0.35 ((Fig. S1).

\section{Micropores}

Micropores covered the whole trunk of male and female cystacanths (Fig. 13) as is commonly observed in adults in other species of acanthocephalans. We did not create SEM images of adults; only whole-mounts were available. We assume, however, that adult $P$. altmani would also exhibit micropores on the cuticular surface of the trunk.

\section{Energy dispersive X-ray analysis (EDXA)}

The EDXA results of the hook cross-sections (Figs. 41-43, Table 4) of $P$. altmani cystacanths show a center core with high level of calcium and phosphorus surrounded by a sulfur-rich exterior. The EDXA spectra of the tip of the hook (Fig. 41) showed a significantly higher relative concentration of sulfur compared to the center core of the mid-hook cross-section (Fig. 43). The EDXA spectra of the edge of the mid-hook cross-section (Fig. 42) again shows the high-sulfur relative concentration observed in the tip of the hook (Fig. 41) as well as the high concentrations of calcium and phosphorus characteristic of the center core of the mid-hook cross-section (Fig. 43). The presence of sulfur, calcium, and phosphorus in the EDXA spectra obtained from the edge of the mid-hook cross-section is attributed to the proximity of the exterior shell to the center core. The relative WT\% concentrations obtained by the TEAM software are reported in Table 4. It is worth noting that these reported WT\% numbers should not be interpreted as compositional. They are, however, indicative of general compositional differences observed between the selected areas. EDXA for spines (Table 5) show low levels of all chemicals but a relatively higher level of calcium in anterior $(6.34 \%)$ and middle (7.81\%) with lowest levels in posterior-most spines. Similar analyses have not been conducted for other species of Profilicollis; thus, comparisons of the chemical profile of hooks and spines could not be made. A baseline for future comparisons is, however, established.

\section{Histopathology}

A series of selected sections (Figs. 37-40) represent the results of the histopathological study of the gull's intestinal sections heavily infected with $P$. altmani. The invading worms were either attached to the gut wall or free in the lumen. There is prominent damage to the intestine where the worms interfaced with the mucosa and submucosa linings. Normal villi in the submucosa are greatly destroyed and disfigured out of shape (Figs. 37, 38). Sections of worms depict some internal anatomy such as lemnisci (Fig. 39). There is the potential for lumen blockage of the gull host gut when worms are present in excessive in numbers (Figs. 38, 39). Hemorrhaging and necrotic epithelial cells are visible around the invading worm with red blood cells free in the host lumen (Figs. 37, 40). The villi of the gull's intestine are dramatically damaged and disfigured out of position with potential compromised absorption and subsequent hemorrhaging and epithelial connective tissue cell necrosis. Hemorrhaging of the blood vessels causes free blood cells and granulocytes to appear in interstitial spaces and in the lumen. Encapsulation has not been observed. The lesions, villi damage and worm number with potential lumen blockage will impact the feeding activity of the gull host.

\section{Discussion \\ Geographically related morphological variations}

Considering its wide range of host and geographical distribution, $P$. altmani exhibits a considerable range of morphometrical variability. The description of adults alone from many species of shore birds under different names in California [42, 54], Canada [75], Texas [77], Peru ([47] and this paper), and Chile [56] depict considerable variability. Table 3 further 


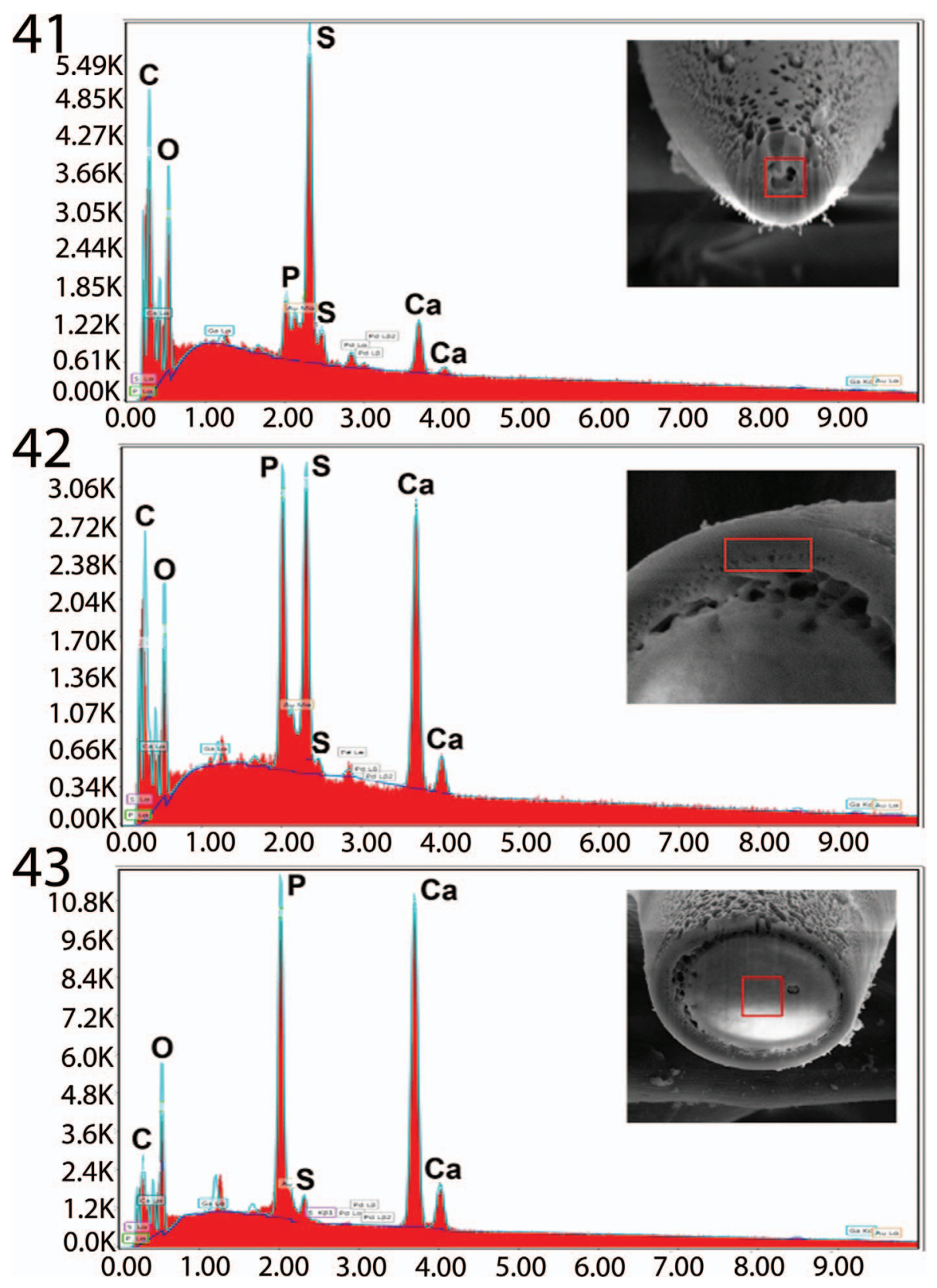

Figures 41-43. X-ray panels of elemental scans of Profilicollis altmani cystacanth hooks. See Table 4 for \% weight of depicted elements. 41. Scan of hook tip. Note the highest level of sulfur compared to the lower levels of phosphorous, magnesium, and calcium. Inset: hook tip. $\mathbf{4 2 .}$ Scan of edge of mid-hook. Note the highest level of calcium and the moderate levels of sulfur and phosphorous. Insert: hook edge. 43. Scan of center of mid-hook. Note the highest level of calcium and the lowest level of sulfur and magnesium. Insert: the center of a mid-hook. Center base of a longitudinal gallium cut showing typical levels of phosphorus, calcium and sulfur content. Insert: SEM of a longitudinal gallium cut hook.

demonstrates extremes of morphological variations (see bolded figures) in some characters of adult populations including size of body, proboscis, receptacle, neck, lemnisci, testes, eggs and number of trunk spines in different hosts and geographical locations. The variability in cystacanths from various mole crab hosts in California, North Carolina, Peru, Chile, and Uruguay (Table 1) also demonstrates the relations between parasite characteristics and host and geography. These relationships have been previously reported for other species of acanthocephalans [16]. Examples of such relationships are discussed below.
A morphometric comparison between our Italian specimens of Centrorhynchus globocaudaus (Zeder, 1800) (Centrorhynchidae) and those from other geographical locations where comparative measurements and counts were reported was discussed by Amin et al. [19]. Centrorhynchus globocaudaus has been reported from many other locations in Asia, Africa, and Europe without taxonomic descriptions leaving their morphologic variability unaccounted for. Most measured specimens were collected from Falco tinnunculus Linn. (Falconidae) thus eliminating host species as a factor in observed 
Table 4. Chemical composition of proboscis hooks of Profilicollis altmani cystacanths from Emerita analoga in Peru.

\begin{tabular}{lccc}
\hline Element* & $\begin{array}{c}\text { Hook } \\
\text { tip }\end{array}$ & $\begin{array}{c}\text { Edge of } \\
\text { mid-hook }\end{array}$ & $\begin{array}{c}\text { Center of } \\
\text { mid-hook }\end{array}$ \\
\hline Phosphorous $(\mathrm{P})$ & 2.66 & 9.65 & 17.26 \\
Magnesium $(\mathrm{Mg})$ & 3.48 & 2.77 & 1.77 \\
Sulfur $(\mathrm{S})$ & 14.82 & 11.11 & 1.60 \\
Calcium $(\mathrm{Ca})$ & 5.13 & 22.18 & 39.31 \\
\hline
\end{tabular}

* Palladium (Pd) and bold (Au) were used to count the specimens and gallium for the cross cut of the spines. These and other elements $(\mathrm{C}, \mathrm{O}, \mathrm{N})$ common in organic matter are omitted. Data are reported in weight (WT\%). Corresponding results are presented in Figures 41-43.

differences in sizes. The specimens that we described had markedly longer proboscis hooks and larger receptacle, and a smaller male reproductive system (testes and cement glands) and lemnisci, especially in males compared to specimens from Ukraine, India, Egypt, Kyrgyzstan, Russia, Georgia, Armenia and former Asian Soviet Republics. Additionally, females from Ukraine and Kyrgyzstan had more proboscis hook rows and those from Ukraine had relatively larger eggs [19]. Such quantitative variations distinguishing the Italian population as a geographical variant had been previously demonstrated in the comparable case of Mediorhynchus papillosus Van Cleave, 1916 (Gigantorhynchidae) by Amin \& Dailey [8]. Amin \& Dailey [8] studied key taxonomic characteristics in various geographical populations of $M$. papillosus, which has a wide range of distribution in at least 73 species of birds outside of North and South America in Asia from Taiwan to the east into China, many of the former Soviet Republics, and to Eastern Europe to the west. Amin \& Dailey [8] compared measurements of specimens from birds in Maryland, Colorado (their study material), Taiwan, Yakutia, Trans-Baikal, Lower Yansi River basin, the Volga basin and Oren Byreg (Orenburg), Ukraine, Bulgaria, China, and Brazil, and demonstrated distinct geographically-based variability, especially in the size of proboscis and its armature, neck, receptacle, and testes, that appeared related to geographical restrictions, intermediate and definitive host specificity and distribution, and host feeding behavior. The population variant of C. globocaudaus from Italy is, nevertheless, comparable to the east-west-intraspecific clinal variants of M. papillosus and could have been considered as distinct species but this notion is dismissed here also for the same reasons. The proposals of Amin and Dailey [8] support the observations of geographical morphometric variations in specimens of Neoechinorhynchus (Hebesoma) personatus Tkach, Sarabeev, Shvetsova, 2014 from the same host species, Mugil cephalus, in the Mediterranean and from the Black Sea ([20], Table 2), would point to intraspecific geographical variations. Van Cleave [73] made a vague reference to "geographical varieties" that was not supported by hard data. See [27, 28, 51] for more information.

Specimens of Acanthocephaloides irregularis Amin, Oguz, Heckmann, Tepe, Kvach, 2011 (Arhythmacanthidae) collected from P. marmoratus (Pallas) in Sukhyi Lyman off the Ukrainian coast were larger than those from the same host species collected from the gulf of Odessa [11]. Size differences of the trunk, proboscis, proboscis receptacle, lemnisci, and testes were attributed to the effect of factors in the geographical location affecting parasite growth and development [11]. Intraspecific variability related to geographical factors has also been demonstrated in Rhadinorhynchus trachuri Harada, 1935 (Rhadinorhynchidae). The observed differences in our $R$. trachuri specimens from Vietnam appear to represent intraspecific variations among Asian and American geographical populations, which may be affected by changes in feeding behavior [6].

Variability in proboscis hooks of Acanthocephalus dirus (Van Cleave, 1931) Van Cleave and Townsend, 1936 (Echinorhynchidae) populations in North America was studied by Amin [1] who noted that largest hooks were progressively longer in more northerly populations. The larger number of hooks per row (11-13) in the Mississippi population reported by Van Cleave [74] appears "to be characteristic to the extreme south" in the Upper Mississippi. The more northern populations were more variable and included specimens with as few as 6 hooks per row in males and 8 in females [1]. Bullock [23] also observed a larger number of proboscis hooks per row in Acanthocephalus jacksoni (Bullock, 1962) from New Hampshire than from Massachusetts. Similarly, Lincicome and Van Cleave [45] reported more and smaller hooks on the proboscis of Leptorhynchoides thecatus, possibly representing more than one species, from Canada than from the United States.

\section{Host related variations}

All structures in our specimens of Acanthogyrus (Acanthosentis) kashmirensis Amin, Heckmann, Zargar, 2017 from Schizothorax plagiostomus Heckel and S. labiatus (McClelland) in the Sandran River in southern Kashmir are larger than those reported by Dhar [26] from his 4 other examined host species in the Jhelum River, and even counts of such features as the number of subcuticular nuclei are considerably greater ([14], page 458). The Sandran River is a tributary of the Jhelum River; both collections are considered sympatric and morphometric differences are attributed to host species. Host species may also have had an impact on the size of lemnisci, being equal or distinctly unequal in our specimens from A. kashmirensis and those of Dhar [26]. They were unequal only in specimens from Bangana diplostoma (Heckel), but equal in specimens from Dhar's [26] 3 other species of fish.

The effect of host species on the size of acanthocephalan parasites has previously been reported in other species as well. See, for example, Amin and Redlin [7] who described considerably larger and more robust specimens of Echinorhynchus salmonis Müller, 1784 (Echinorhynchidae) from bloater, Coregonus hoyi Milner (Salmonidae), than from rainbow smelt, Osmerus mordax Mitchill (Osmeridae), collected from the same waters of Lake Michigan. Host species also affected corresponding differences in the size of proboscis, proboscis hooks, proboscis receptacle, lemnisci, testes, and cement glands as well as body form and differential growth rates in specimens from each host species. Linear regression analysis indicated that curves describing the growth pattern of these characters by worm length (age) were significantly different as a function of host species [7]. The larger worms recovered from $C$. hoyi invariably showed a higher regression coefficient compared to 
Table 5. Chemical composition of trunk spines of Profilicollis altmani cystacanths from Emerita analoga in Peru.

\begin{tabular}{lcccc}
\hline Element* & $\begin{array}{c}\text { Single anterior } \\
\text { spine }\end{array}$ & $\begin{array}{c}\text { Several spines in } \\
\text { anterior }\end{array}$ & $\begin{array}{c}\text { Single middle } \\
\text { spine }\end{array}$ & $\begin{array}{c}\text { Posterior-most } \\
\text { spine }\end{array}$ \\
\hline Phosphorous (P) & 3.93 & 2.61 & 5 & $1.15-1.34$ \\
Sulfur (S) & 3.21 & 2.7 & 2.56 & $3.28-3.94$ \\
Calcium (Ca) & 6.34 & 4.07 & 7.81 & $2.19-2.26$ \\
\hline
\end{tabular}

* Palladium $(\mathrm{Pd})$ and gold $(\mathrm{Au})$ were used to count the specimens and gallium for the cross cut of the spines. These and other elements $(\mathrm{C}, \mathrm{O}$, $\mathrm{N})$ common in organic matter are omitted. Data are reported in weight (WT\%).

those from $O$. mordax in all characters. The taxonomic implications are vast and include the possible description of extremely variable populations from different host species (and geographies) as distinct species. We do not believe that this is an issue in our present investigation as long as we acknowledge that host species does account for the extreme differences in the morphometric characterization of the studied populations.

Comparative measurements of taxonomic characteristics of Neoechinorhynchus (Neoechinorhynchus) johnii Yamaguti, 1939 show that our specimens from 4 host species in Vietnam collectively had the largest size of trunk, proboscis, proboscis hooks, neck, and testes, and more cement gland nuclei compared to other specimens from India, Pakistan, and East China ([17], Table 2). When those measurements were broken down by host species ([17], Table 3), the relationship of host species to the size of taxonomically important structures became quite apparent.

Relevant studies on species of the genus Acanthocephalus and intraspecific variability in Acanthocephalus dirus [1, 2] explored the adaptability of acanthocephalans to a wide range of intermediate and definitive hosts affecting population dispersal and diversification. These examples, among others, point to plasticity in the Acanthocephala and the influence of biotic factors on their diversification. Our study, bearing out the possible existence of polymorphs of $P$. altmani is another demonstration of the variabilities within the Acanthocephala. This case of closely related, yet distinguishable, populations of one species can serve as a model for determining host and habitat specificity mechanisms.

\section{Molecular analysis}

Our molecular results corroborate that despite morphological variability and host diversity, $P$. altmani displays low genetic variation and that there is no structure on the basis of hosts (intermediate and definitive) nor geography. Likely, the high mobility of the definitive hosts belonging to the family Charadriiformes, including the seagulls $L$. dominicanus, L. modestus, C. maculipennis and L. pipixcan, which are continuously migrating across oceans and hemispheres, contribute to the high dispersal of acanthocephalan eggs, causing genetic homogenization of populations and then, lack of phylogeographic structure $[46,57,59,60]$. Future studies should evaluate if the observed pattern derived from the analysis of a mitochondrial gene, holds for more variable nuclear markers (e.g., SNPs). Finally, other studies should tackle the relationships among species of the family Polymorphidae, which are still unstable, suggesting that the limits of the genera that constitute this family need to be further evaluated.

\section{Micropores}

The micropores of $P$. altmani, like those reported from other species of the Acanthocephala, are associated with internal crypts and vary in diameter and distribution in different trunk regions corresponding to differential absorption of nutrients. We have reported micropores in a large number of acanthocephalan species [38] and in a few more since, and demonstrated the tunneling from the cuticular surface into the internal crypts by TEM. Amin et al. [9] gave a summary of the structural-functional relationship of the micropores in various acanthocephalan species including Rhadinorhynchus ornatus Van Cleave, 1918, Polymorphus minutus (Goeze, 1782) Lühe, 1911, Moniliformis moniliformis (Bremser, 1811) Travassos (1915), Macracanthorhynchus hirudinaceus (Pallas, 1781) Travassos (1916, 1917), and Sclerocollum rubrimaris Schmidt and Paperna, 1978. Wright and Lumsden [79] and Byram \& Fisher [24] reported that the peripheral canals of the micropores are continuous with canalicular crypts. These crypts appear to "constitute a huge increase in external surface area ... implicated in nutrient uptake." Whitfield [78] estimated a 44-fold increase at a surface density of 15 invaginations per $1 \mu^{2}$ of Moniliformis moniliformis (Bremser, 1811) Travassos, 1915 tegumental surface. The micropores and the peripheral canal connections to the canaliculi of the inner layer of the tegument were demonstrated by transmission electron micrographs in Corynosoma strumosum (Rudolphi, 1802) Lühe, 1904 from the Caspian seal Pusa caspica (Gmelin) in the Caspian Sea (Figs. 19, 20 of [10]) and in Neoechinorhynchus personatus Tkach, Sarabeev, Shvetsova, 2014 from Mugil cephalus Linn. in Tunisia (Figs. 26, 29, 30 in [20]).

\section{Energy dispersive X-ray analysis (EDXA)}

Our studies of acanthocephalan worms have usually involved X-ray scans (EDXA) of FIB-sectioned hooks and spines [35-37, 67]. Hooks and spines are evaluated for chemical ions with sulfur $(\mathrm{S})$, calcium $(\mathrm{Ca})$ and phosphorus $(\mathrm{P})$ being the prominent elements. Sulfur is usually seen at the outer edge of large hooks and calcium and phosphorus are major ions in the base and middle of hooks where tension and strength are paramount for hook function. Large hooks play a major role for host tissue attachment. Results of the X-ray analysis of the FIB-sectioned hooks and spines (dual beam SEM) of $P$. altmani cystacanths show differential composition and distribution of metals in different hook and spine parts characteristic of that species. Hook tips of $P$. altmani showed the highest level of sulfur (14.82\%) and lowest levels of calcium (5.13\%) and phosphorus $(2.66 \%)$ while the mid-hook center had highest 
level of calcium $(39.31 \%)$ and phosphorus (17.26\%) and lowest level of sulfur (1.6\%). Similarly, in Cavisoma magnum (Southwell, 1927) Van Cleave, 1931 from Mugil cephalus in the Arabian Sea, unusually high levels of sulfur in hook tips (43.51 wt. \%) and edges (27.46 wt. \%) were found [15]. This element (sulfur) is part of the prominent outer layer of most acanthocephalan hooks and is a major contributor of the hardening process of this attachment structure. Our results are comparable to those of mammalian teeth enamel. The center and base of hooks of the same worms had negligible sulfur levels and contained mostly phosphorus and calcium, the two other essential elements for hook structure [15]. The chemical elements present in the hooks are typical for acanthocephalans [36, 37]. Note the moderate level of sulfur in the outer layer of the hook of $P$. altmani, which is different than in other acanthocephalans. The high sulfur content shows up in the outer edge of X-ray analysis of hooks (Table 4, 5, [15]). The hook center in mid cuts has a different chemical profile than the cortical layer (Table 4).

This is the first investigation of the chemical profile in spines of cystacanths of any species of acanthocephalan. The anterior, middle and posterior trunk spines of $P$. altmani show low levels of all chemicals but the calcium showed relatively higher levels than phosphorus and sulfur in all spines, reaching $7.81 \%$ in middle spines with the posterior spines having the lowest levels. These results suggest that trunk spines do contribute to the attachment and adhering to host tissue. There are no comparative studies of cystacanth spines to compare notes with and this study will serve as a reference line against which future studies can be evaluated.

X-ray scans analysis provide insight into the hardened components, e.g., calcium, sulfur, and phosphorus, of acanthocephalan hooks. The EDXA appears to be species-specific, as in fingerprints. For example, EDXA is shown to have significant diagnostic value in acanthocephalan systematics, e. g., Moniliformis cryptosaudi Amin, Heckmann, Sharifdini, Albayati, 2019 was erected based primarily on its EDXA pattern [18]. Our methodology for the detection of the chemical profile of hooks in the Acanthocephala has also been used in other parasitic groups including the Monogenea [64, 66] and Cestoda [65]. We also provide molecular data to explain and clarify our findings.

\section{Histopathology}

Normal host intestinal tissue is evident in all sections showing prominent layers of the host intestine, especially the mucosa, sub-mucosa, and fibro-serosa. The sections are made from 4 heavily infected gulls, L. belcheri intestines packed with adult specimens of $P$. altmani. The mucosa is lined with simple columnar epithelial cells and goblet cells (Fig. 37). Host villi are compressed and distorted. There is a loss of the typical columnar epithelium lining (CEL) of the villi. The loss of the normal CEL of the mucosa and obstruction of the surface of the host mucosa will deprive it of nutrient absorption (Figs. 3840). There is obstruction of the absorptive surface and blockage of the intestinal lumen due to the size of adult worms that often appear to occupy most of the host intestinal lumen. Worms have clearly invaded through the mucosal-submucosal layers causing observed cell necrosis, blood loss and destruction of the absorbing epithelial surface of the mucosa. Within the host, worms contained eggs and sperm (Fig. 40). The hemorrhaging is primarily due to capillary destruction of the host intestine. There is no evidence of encapsulation of worms by the host.

The histopathology results are similar to others described by Amin et al. [13] of Moniliformis saudi Amin, Heckmann, Mohammed, Evans, 2016 (Moniliformidae) in Paraechinus aethiopicus (Ehrenberg) [13] from Saudi Arabia and of Centrorhynchus globirostris Amin, Heckmann, Wilson, Keele, Khan, 2015 (Centrorhynchidae) in Centropus sinensis (Stephens) from Pakistan [39] as well as those of Pomphorhynchus kashmirensis Kaw, 1941 (Pomphorhynchidae) in Schizothorax plagiostomus Heckel [12] from Kashmir. Gonzales-Viera et al. [32] provided the only other histopathological study of $P$. altmani in another definitive host species, the gray gull, Leucophaeus modestus (Tschudi) from the Peruvian coast. Their sections were different from ours focusing on the attachment sites featuring proboscis invasion of the villi with adjacent central necrosis, inflammatory infiltrates, hyperplasia, granuloma in the submucosa, and peripheral dense fibrous and vascularized connective tissue. Gonzales-Viera ([32], page 115) further concluded that $P$. altmani "causes severe eosinophilic granulomatous enteritis in the gray gull."

\section{Concluding remarks}

This work brings into focus the importance of including studies of intraspecific variability in immatures and adults of acanthocephalans, elucidating developmental changes and adaptations. In addition to the utility of molecular profiles for comparative studies, the inclusion of Energy dispersive X-ray analyses of hooks and spines, as we present in this work, will contribute a valuable diagnostic tool often needed in taxonomic studies. When possible, histopathological studies will provide an additional dimension in studies of host-parasite relationships.

\section{Supplementary material}

Supplementary material is available at https://www.parasitejournal.org/10.1051/parasite/2022005/olm

Table S1. Species of acanthocephalans, host (intermediate (I) and definitive (D)), location, and GenBank accession number of the sequences used in the phylogenetic analysis.

Figure S1. Genealogical relationships of haplotypes of the COI gene of specimens of the genus Profilicollis recovered in a Bayesian inference analysis. Numbers next to nodes refer to support values. Bayesian posterior probability values are shown left of the diagonal and Bootstrap proportions gathered in the Maximum Likelihood analysis $\left(\mathrm{L}_{\mathrm{n}}=-2,762.492266\right)$ are shown right of the diagonal. GenBank accession numbers are included in the terminal labels. Animal silhouettes next to the tree indicate host of each species of Profilicollis.

Figure S2. "Restaurante" - A painting by Denise de Solminihac, illustrating the research presented in this paper.

\section{Conflict of interest and ethical values}

The authors declare compliance with relevant ethical values as well as no conflict of interest. 
Acknowledgements. This project was supported by the Department of Biology, Brigham Young University (BYU), Provo, Utah, by an Institutional Grant from the Parasitology Center, Inc. (PCI), Scottsdale, Arizona and by Postdoctoral Fondecyt (SMR, grant \# 3190348). We are grateful to those who began the investigations of $P$. altmani in Emerita analoga in Peru including Pablo Peña and Olger Linares in 1976 in Cuzco during May 1977 (Summary Book of the V National Congress of Biology, p. 158). We thank Madison Laurence, Bean Museum (BYU), Provo, Utah for expert help in the preparation and organization of plates and figures and Michael Standing, Electron Optics Laboratory (BYU), for his technical help and expertise in the preparation and production of the SEM images and the EDXA data. We are also grateful to Dr. Ralph Appy, Cabrillo Marine Aquarium, San Pedro, California for kindly providing the $P$. altmani cystacanth material from E. analoga used for the molecular analysis.

\section{References}

1. Amin OM. 1984. Variability and redescription of Acanthocephalus dirus (Acanthocephala: Echinorhynchidae) from freshwater fishes in North America. Proceedings of the Helminthological Society of Washington, 51, 225-237.

2. Amin OM. 1985. Hosts and geographical distribution of Acanthocephalus (Acanthocephala: Echinorhynchidae) from North American freshwater fishes, with a discussion of species relationships. Proceedings of the Helminthological Society of Washington, 51, 210-220.

3. Amin OM. 1992. Review of the genus Polymorphus Lühe, 1911 (Acanthocephala: Polymorphidae), with the synonymization of Hexaglandula Petrochenko, 1950 and Subcorynosoma Hoklova, 1967, and a key to the species. Qatar University of Science Journal, 12, 115-123.

4. Amin OM. 1998. Marine Flora and Fauna of the Eastern United States: Acanthocephala. NOAA Tech. Rep. NMFS, U. S. Dept. Comm, $28 \mathrm{p}$.

5. Amin OM. 2013. Classification of the Acanthocephala. Folia Parasitologica, 60, 273-305.

6. Amin OM. 2019. Redescription of Rhadinorhynchus trachuri Harada, 1935 (Acanthocephala: Rhadinorhynchidae) from marine fish in Vietnam and California with a discussion of its zoogeography. Acta Parasitologica, 65, 77-89.

7. Amin OM, Redlin MJ. 1980. The effect of host species on growth and variability of Echinorhynchus salmonis Müller, 1784 (Acanthocephala: Echinorhynchidae), with special reference to the status of the genus. Systematic Parasitology, 2, 9-20.

8. Amin OM, Dailey MD. 1998. Description of Mediorhynchus papillosus (Acanthocephala: Gigantorhynchidae) from a Colorado, U.S.A., population, with a discussion of morphology and geographical variability. Journal of the Helminthological Society of Washington, 65, 189-200.

9. Amin OM, Heckmann RA, Radwan NA, Mantuano JS, Alcivar MAZ. 2009. Redescription of Rhadinorhynchus ornatus (Acanthocephala: Rhadinorhynchidae) from skipjack tuna, Katsuwonus pelamis, collected in the Pacific Ocean off South America, with special reference to new morphological features. Journal of Parasitology, 95, 656-664.

10. Amin OM, Heckmann RA, Halajian A, El-Naggar AM. 2011. The morphology of an unique population of Corynosoma strumosum (Acanthocephala, Polymorphidae) from the Caspian seal, Pusa caspica, in the land-locked Caspian Sea using SEM, with special notes on histopathology. Acta Parasitologica, 56, $438-445$.
11. Amin OM, Oguz MC, Heckmann RA, Tepe Y, Kvach Y. 2011. The description of Acanthocephaloides irregularis $\mathrm{n}$. $\mathrm{sp}$. (Acanthocephala: Arhythmacanthidae) from marine fish off the Ukranian Black Sea coast. Systematic Parasitology, 80, 125-135.

12. Amin OM, Heckmann RA, Zargar UR, Chisti MZ. 2012. The morphology of the long forgotten Pomphorhynchus kashmirensis (Acanthocephala: Pomphorhynchidae) from freshwater fish in Kashmir using SEM, with notes on histopathology. Scientia Parasitologica, 13, 93-99.

13. Amin OM, Heckmann RA, Mohamed O, Evans RP. 2016. Morphological and molecular descriptions of Moniliformis saudi sp. n. (Acanthocephla: Moniliformidae) from the desert hedgehog Paraechinus aethiopicus (Ehrenberg) in Saudi Arabia, with a key to species and notes on histopathology. Folia Parasitologica, 63, 014.

14. Amin OM, Heckmann RA, Zargar OR. 2017. Description of a new quadrigyrid acanthocephalan from kashmir, with notes on metal analysis and histopathology, and a key to species the subgenus Acanthosentis from the Indian subcontinent. Journal of Parasitology, 103, 458-470.

15. Amin OM, Heckmann RA, Bannai M. 2018. Cavisoma magnum (Cavisomidae), a unique Pacific acanthocephalan redescribed from an unusual host, Mugil cephalus (Mugilidae), in the Arabian Gulf, with notes on histopathology and metal analysis. Parasite, 25, 5.

16. Amin OM, Rodríguez SM, Heckmann RA. 2019. Morphological updates and molecular description of Heterosentis holospinus Amin, Heckmann, Ha, 2011 (Acanthocephala: Arhythmacanthidae) in the Pacific Ocean off Vietnam. Parasite, 26, 73.

17. Amin OM, Chaudhary A, Heckmann RA, Nguyen VH, Singh HS. 2019. Redescription and molecular analysis of Neoechinorhynchus (Neoechinorhynchus) johnii Yamaguti, 1939 (Acanthocephala: Neoechinorhynchidae) from the Pacific Ocean off Vietnam. Parasite, 26, 43.

18. Amin OM, Heckmann RA, Sharifdini M, Albayati NY. 2019. Moniliformis cryptosaudi n. sp., (Acanthocephala: Moniliformidae) from the long-eared hedgehog Hemiechinus auratus (Gmelin) (Erinaceidae) in Iraq; a case of incipient cryptic speciation related to M. Saudi in Saudi Arabia. Acta Parasitologica, 64, 195-204.

19. Amin OM, Heckmann RA, Dallarés S, Constenla M, Rubini S. 2020. Description and molecular analysis of an Italian population of Centrorhynchus globocaudatus (Zeder, 1800) Lühe, 1911 (Acanthocephala: Centrorhynchidae) from Falco tinnunculus (Falconidae) and Buteo buteo (Accipitridae). Journal of Helminthology, 94, 1-21.

20. Amin OM, Sharifdini M, Heckmann RA, Rubtsova N, Chine HJ. 2020. On the Neoechinorhynchus agilis (Acanthocephala: Neoechinorhynchidae) complex, with the description of Neoechinorhynchus ponticus n. sp. from Chelon auratus Risso in the Black Sea. Parasite, 27, 48.

21. Balboa L, Hinojosa A, Riquelme C, Rodríguez S, Bustos J, George-Nascimento M. 2009. Alloxenic distribution of cystacanths of two Profilicollis species in sympatric crustacean hosts in Chile. Journal of Parasitology, 95, 1205-1208.

22. Bancroft JD, Gamble M. 2001. Theory and practice of histological techniques, 5th edn. Edingburough, U.K.: Churchill Livingston, $800 \mathrm{p}$.

23. Bullock WL. 1962. A new species of Acanthocephalus from New England fishes with observations on variability. Journal of Parasitology, 48, 442-451.

24. Byram JE, Fisher FM Jr. 1973. The absorptive surface of Moniliformis dubius (Acanthocephala). 1. Fine structure. Tissue and Cell, 5, 553-579. 
25. Constancio LF. 2011. Effects of season, size and parasitism by the acanthocephalan, Profilicollis altmani, on the carotenoid concentration and composition of the Pacific mole crab, Emerita analoga. M.Sc. thesis, San Luis Obispo: California Polytechnic State University, $177 \mathrm{p}$.

26. Dhar RL. 1972. Studies on helminth parasites of fishes of Jammu \& Kashmir. Ph.D. Thesis, Srinagar, Kashmir: University of Kashmir, 118 p.

27. Folmer O, Black M, Hoeh W, Lutz R, Vrijenhoek R. 1994. DNA primers for amplification of mitochondrial cytochrome $\mathrm{c}$ oxidase subunit I from diverse metazoan invertebrates. Molecular Marine Biology and Biotechnology, 3, 294-299.

28. García-Varela M, Nadler SA. 2006. Phylogenetic relationships among Syndermata inferred from nuclear and mitochondrial gene sequences. Molecular Phylogenetic and Evolution, 40, 61-72.

29. García-Varela M, Ponce de León G. 2008. Validating the systematic position of Profilicollis Meyer, 1931 and Hexaglandula Petrochenko, 1950 (Acanthocephala: Polymorphidae) using cytochrome C oxidase (COX 1). Journal of Parasitology, 94, 212-217.

30. Goedknegt MA, Havermans J, Waser AM, Luttikhuizen PC, Velilla E, Camphuysen KCJ, van der Meer J, Thieltges DW. 2017. Cross-species comparison of parasite richness, prevalence, and intensity in a native compared to two invasive brachyuran crabs. Aquatic Invasions, 12, 201-212.

31. Gomez-Puerta LA, Naupay A. 2019. Algunos helmintos parásitos de la gaviota peruana. Revista Peruana de Biología, 26, 149-156.

32. Gonzales-Viera O, Luján-Vega C, Chavera-Castillo A, Cárdenas-Callirgos J, Tantaleán VM. 2009. Lesiones patológicas causadas por Profilicollis altmani (Perry, 1942) Van Cleave, 1947 (Acanthocephala) en una gaviota gris (Leucophaeus modestus) (Tschudi, 1843) de la Costa Peruana. Neotropical Helminthology, 3, 115-120.

33. Goulding TC, Cohen CS. 2014. Phylogeography of a marine acanthocephalan: lack of cryptic diversity in a cosmopolitan parasite of mole crabs. Journal of Biogeography, 41, 965-976.

34. Hay E, Jorge F, Poulin R. 2018. The comparative phylogeography of shore crabs and their acanthocephalan parasites. Marine Biology, 165, 69.

35. Heckmann RA. 2006. Energy dispersive x-ray analysis (EDXA) in conjunction with electron optics, a tool for analyzing aquatic animal parasite diseases and deaths, an update. Proceedings of Parasitology, 41, 1-18.

36. Heckmann RA, Amin OM, Standing MD. 2007. Chemical analysis of metals in Acanthocephalans using energy dispersive X-ray analysis (EDXA, XEDS) in conjunction with a scanning electron microscope (SEM). Comparative Parasitology, 74, 388-391.

37. Heckmann RA, Amin OM, Radwan NAE, Standing MDD, Eggett L, El Naggar AM. 2012. Fine structure and energy dispersive X-ray analysis (EDXA) of the proboscis hooks of Radinorynchus ornatus, Van Cleave 1918 (Rhadinorynchidae: Acanthocephala). Scientia Parasitologica, 13, 37-43.

38. Heckmann RA, Amin OM, El-Naggar AM. 2013. Micropores of Acanthocephala, a scanning electron microscopy study. Scientia Parasitologica, 14, 105-113.

39. Heckmann RA, Amin OM, Khan A. 2015. Histopathology of Centrorhynchus globirostris (Acanthocephala: Centrorhynchidae) infecting the intestine of the pheasant crow, Centropus sinensis (Stephens) in Pakistan. Scientia Parasitologica, 16, 151-155.

40. Hoklova IG. 1974. Revision of the genus Profilicollis Meyer, $1931=$ syn. Falsificollis Webster, $1948=$ Parafilicollis Petrotschenko, 1956 Acanthocephala: Filicollidae). Helminthologia, 15, 803-811.

41. Iannacone J, Alvariño L, Bolognesi B. 2007. Aspectos cuantitativos de los metazoos parásitos del muy muy Emerita analoga (Stimpson) (Decapoda, Hippidae) en Chorrillos, Lima, Perú. Neotropical Helminthology, 2, 59-67.

42. Karl JE Jr. 1967. Studies on the systematics and life history of Polymorphus altmani (Perry). Ph.D. Dissertation. Baton Rouge, Louisiana: Louisiana State University, $132 \mathrm{p}$.

43. Kiernan JA. 2001. Histological and histochemical methods: theory and practice. Edingburgh, U.K.: Churchill Livingston, 520 p.

44. Lee RE. 1992. Scanning electron microscopy and X-ray microanalysis. New Jersey: Prentice Hall, Englewood Cliffs, $464 \mathrm{p}$.

45. Lincicome DR, Van Cleave HJ. 1949. Review and redescription of Leptorhynchoides thecatus. Transactions of the American Microscopical Society, 68, 304-313.

46. Lorenti E, Rodríguez SM, Cremonte F, D’Elía G, Diaz JI. 2018. Life cycle of the acanthocephalan Profilicollis chasmagnathi (Holcman-Spector, Mañé-Garzón \& Dei-Cas, 1977) in the Patagonian coast of Argentina: morphological and molecular analyses. Journal of Parasitology, 104, 479-485.

47. Mateo E, Cordova R, Guzmán E. 1982. Polymorphus (Profilicollis) bullocki. Nueva especie de acantocéfalo hallado en la gaviota Larus belcheri en el Perú. Boletin de Lima, 4, 73-78.

48. Mateo E, Córdova R, Guzmán E. 1983. Polymorphus (Profilicollis) bullocki acantocéfalo de la gaviota Larus belcheri: contribución a su ciclobiológico. Boletín de Lima, 26, 67-72.

49. Mayer KA, Dailey MD, Miller MA. 2003. Helminth parasites of the southern sea otter Enhydra lutris nereis in Central California: abundance, distribution and pathology. Diseases of Aquatic Oganisms, 53, 77-88.

50. Meza VJR, Cabrera YMS. 2011. Emerita analoga consumption "muy muy" and infection with larval Profilicollis altmani in the southern beaches of Lima. Revista EciPeru, 8, 163-166.

51. Nguyen LT, Schmidt HA, von Haeseler A, Minh BQ. 2015. IQTREE: a fast and effective stochastic algorithm for estimating maximum-likelihood phylogenies. Molecular Biology and Evolution, 32, 268-274.

52. Nickol BB, Crompton D, Searle D. 1999. Reintroduction of Profilicollis Meyer, 1931, as a genus in Acanthocephala: significance of the intermediate host. Journal of Parasitology, 85, 716-718.

53. Nickol BB, Heard RW, Smith NF. 2002. Acanthocephalans from crabs in the southeastern US, with the first intermediate hosts known for Arhythmorhynchus frassoni and Hexaglandula corynosoma. Journal of Parasitology, 88, 79-83.

54. Perry ML. 1942. A new species of the acanthocephalan Filicollis. Journal of Parasitology, 28, 385-388.

55. Petrochenko VI (1958) Acanthocephala of domestic and wild animals, Vol. 2. Moscow: Izdatel'stvo Akademii Nauk S.S.S.R. (English translation by Israel Program for Scientific Translations Ltd., 1971), 478 p.

56. Riquelme C, George-Nascimento M, Balboa L. 2006. Morfometría y fecundidad de Profilicollis bullocki Mateo, Córdova \& Guzmán 1982 (Acanthocephala: Polymorphidae) en especies simpátricas de aves costeras de Chile. Revista Chilena de Historia Natural, 79, 465-474.

57. Rodríguez SM, D’Elía G. 2016. Pan-American marine coastal distribution of Profilicollis altmani based on morfometric and phylogenetic analysis of Cystacanths from the mole crab Emerita brasiliensis. Journal of Helminthology, 91, 371-375.

58. Rodríguez SM, Valdivia N. 2017. Mesoscale spatiotemporal variability in a complex host-parasite system influenced by intermediate host body size. PeerJ, 5, e3675.

59. Rodríguez SM, D’Elía G, Valdivia N. 2017. The phylogeny and life cycle of two species of Profilicollis (Acanthocephala: Polymorphidae) in marine hosts off the Pacific coast of Chile. Journal of Helminthology, 91, 589-596. 
60. Rodríguez SM, Diaz JI, D’Elía G. 2017. Morphological and molecular evidence on the existence of a single species of thorny-headed acanthocephalans of the genus Profilicollis inhabits the estuaries of the Atlantic and Pacific coast of southern South America. Systematic Parasitology, 94, 527-533.

61. Rodríguez SM, Burgos K, Gutiérrez B, Escares V, Byers JE. 2020. First report of foraging behavior on Pacific mole crabs (Emerita analoga) by dogs (Canis lupus familiaris) on the coast of Valdivia, Chile. Gayana, 84, 158-162.

62. Ronquist F, Huelsenbeck JP. 2003. MrBayes 3: Bayesian phylogenetic inference under mixed models. Bioinformatics, 19, 1572-1574.

63. Royal L, Dailey M, Demaree R, Sakanari J. 2004. Acanthocephala cystacanth infections in sand crabs from Bodega Bay, California. California Fish and Game, 90, 36-41.

64. Rubtsova NY, Heckmann RA. 2019. Structure and morphometrics of Ancyrocephalus paradoxus (Monogenea: Ancyrocephalidae) from Sander lucioperca (Percidae) in Czechia. Helminthologia, 56, 11-21.

65. Rubtsova NY, Heckmann RA. 2020. Morphological features and structural analysis of plerocercoids of Spirometra erinaceieuropaei (Cestoda: Diphyllobothriidae) from European pine marten, Martes martes (Mammalia: Mustelidae) in Ukraine. Comparative Parasitology, 87, 109-117.

66. Rubtsova NY, Heckmann RA, Smit WS, Luus-Powell WJ, Halajian A, Roux F. 2018. Morphological studies of developmental stages of Oculotrema hippopotami (Monogenea: Polystomatidae) infecting the eye of Hippopotamus amphibius (Mammalia: Hippopotamidae) using SEM and EDXA with notes on histopathology. Korean Journal of Parasitology, 56, 463-475.

67. Standing MD, Heckmann RA. 2014. Features of Acanthocephalan hooks using dual beam preparation and XEDS phase maps. Hartford, CT: Microscopy and Microanalysis Meeting. Poster. Subm. No. 0383-00501.

68. Tamura K, Stecher G, Peterson D, Filipski A, Kumar S. 2013. MEGA6: molecular evolutionary genetics analysis version 6.0. Molecular Biology and Evolution, 30, 2725-2729.

69. Tantaleán M, Cárdenas J. 2004. Considerations about Profilicollis altmani (Perry, 1942) Van Cleave, 1947 in Peru. Revista Peruana de Biología, 11, 109-111.
70. Tantaleán M, Cárdenas J, Güere R. 2002. Profilicollis altmani (Perry, 1942) Van Cleave, 1947 (Acanthocephala) en el Perú. Con notas sobre la infección experimental de mamíferos marinos. Revista Peruana de Biología, 9, 49-51.

71. Tantaleán M, Sánchez L, Gómez L, Huiza A. 2005. Acantocéfalos del Perú. Revista Peruana de Biología, 12, 83-92.

72. Trifinoupoulus J, Nguyen LT, von Haeseler A, Minh BQ. 2016. W-IQ-TREE: a fast online phylogenetic tool for maximum likelihood analysis. Nucleic Acids Research, 44, 232-235.

73. Van Cleave HJ. 1919. Acanthocephala from the Illinois River, with description of species and a synopsis of the family Neoechinorhynchidae. Bulletin of the Illinois Natural History Survey, 13, 225-257.

74. Van Cleave HJ. 1931. New Acanthocephala from fishes of Mississippi and a taxonomic reconsideration of forms with unusual numbers of cement glands. Transactions of the American Microscopical Society, 50, 348-363.

75. Van Cleave HJ. 1947. Analysis of distinctions between the acanthocephalan genera Filicollis and Polymorphus, with description of a new species of Polymorphus. Transactions of the American Microscopical Society, 66, 302-313.

76. Van Cleave HJ, Townsend LH. 1936. On the assignment of Echinorhynchus dirus to the genus Acanthocephalus. Proceedings of the Helminthological Society of Washington, 3, 63.

77. Webster JD. 1948. A new acanthocephalan from the sanderling. Transactions of the American Microscopical Society, 67, 66-69.

78. Whitfield PJ. 1979. The biology of parasitism: an introduction to the study of associating organisms. Baltimore, Maryland: University Park Press, $277 \mathrm{p}$.

79. Wright RD, Lumsden RD. 1969. Ultrastructure of the tegumentary pore canal system of the acanthocephalan Moniliformis dubius. Journal of Parasitology, 55, 993-1003.

80. Zambrano D, George-Nascimento M. 2010. Parasitism by Profilicollis bullocki (Acanthocephala: Polymorphidae) in Emerita analoga (Anomura, Hippidae), according to contrasting conditions of abundance of definitive hosts in Chile. Revista de Biología Marina y Oceanografía, 45, 277-283.

Cite this article as: Amin OM, Rodríguez SM, Rubtsova N, Heckmann RA, Peña C, Castro T, Rivera F \& D’Elía G. 2022. A comparative assessment of the morphology of Profilicollis altmani (Acanthocephala, Polymorphidae) from crustaceans and shore birds in Peru, with special notes on hook elemental analysis (EDXA), SEM imaging, histopathology, and molecular profile. Parasite 29, 9.

Reviews, articles and short notes may be submitted. Fields include, but are not limited to: general, medical and veterinary parasitology; morphology, including ultrastructure; parasite systematics, including entomology, acarology, helminthology and protistology, and molecular analyses; molecular biology and biochemistry; immunology of parasitic diseases; host-parasite relationships; ecology and life history of parasites; epidemiology; therapeutics; new diagnostic tools.

All papers in Parasite are published in English. Manuscripts should have a broad interest and must not have been published or submitted elsewhere. No limit is imposed on the length of manuscripts.

Parasite (open-access) continues Parasite (print and online editions, 1994-2012) and Annales de Parasitologie Humaine et Comparée (1923-1993) and is the official journal of the Société Française de Parasitologie. 